\title{
Cardiopharyngeal Progenitor Specification: Multiple Roads to the Heart and Head Muscles
}

\author{
Benjamin Swedlund ${ }^{1}$ and Fabienne Lescroart ${ }^{2}$ \\ ${ }^{1}$ Laboratory of Stem Cells and Cancer, Université Libre de Bruxelles, 1070 Brussels, Belgium \\ ${ }^{2}$ Aix Marseille Univ, INSERM, MMG U1251, 13005 Marseille, France \\ Correspondence: fabienne.lescroart@univ-amu.fr
}

During embryonic development, the heart arises from various sources of undifferentiated mesodermal progenitors, with an additional contribution from ectodermal neural crest cells. Mesodermal cardiac progenitors are plastic and multipotent, but are nevertheless specified to a precise heart region and cell type very early during development. Recent findings have defined both this lineage plasticity and early commitment of cardiac progenitors, using a combination of single-cell and population analyses. In this review, we discuss several aspects of cardiac progenitor specification. We discuss their markers, fate potential in vitro and in vivo, early segregation and commitment, and also intrinsic and extrinsic cues regulating lineage restriction from multipotency to a specific cell type of the heart. Finally, we also discuss the subdivisions of the cardiopharyngeal field, and the shared origins of the heart with other mesodermal derivatives, including head and neck muscles.

$\mathrm{T}_{\mathrm{h}}^{\mathrm{h}}$ hroughout the animal kingdom, organogenesis takes place early during embryonic development. This developmental process consists of the formation of organs through the progressive commitment and specification of progenitor cells, their migration toward the final location of the organ, and their signaling interactions with surrounding tissues. Organogenesis starts with the commitment of multipotent and plastic progenitors that will progressively acquire the molecular program of more restricted progenitors and finally differentiate into mature functional cells.

The heart is the first organ to form in mammals and arises from the specification of cardiac progenitor cells, which can be identified as early as during gastrulation (Kinder et al. 1999) and which represent the building blocks of cardiac development. Cardiac progenitors are included in a larger mesodermal population termed the cardiopharyngeal field (CPF) that contributes to both the heart and skeletal muscles of the head and neck (Diogo et al. 2015). In vertebrates, the first specified cardiac cells generally express Nkx2-5 (Harvey 2002), which notably also marks certain skeletal muscle progenitors of the head (Diogo et al. 2015). Nevertheless, cardiopharyngeal progenitor cells (CPCs) can be identified earlier during development, before the onset of Nkx2-5 expression, and there are now several lines of evidence showing that the fate of CPCs is specified during or prior to gastrulation.

In mammals, cardiac progenitors will build a four-chambered heart with two atria and two

Editors: Benoit G. Bruneau and Paul R. Riley

Additional Perspectives on Heart Development and Disease available at www.cshperspectives.org

Copyright (C) 2020 Cold Spring Harbor Laboratory Press; all rights reserved; doi: 10.1101/cshperspect.a036731

Cite this article as Cold Spring Harb Perspect Biol 2020;12:a036731 
ventricles, consisting of different cell types including cardiomyocytes (CMs), endocardial cells (ECs) forming the inner layer, epicardialderived cells (EPDCs) at the outer layer, and smooth muscle cells (SMCs) (Lescroart and Meilhac 2012). It is now well established that vertebrate cardiogenesis occurs through progressive addition of several populations of progenitors to the forming linear heart tube. An early differentiating population of progenitors, termed the first heart field (FHF), gives rise to the left ventricle (LV) and some atrial cells, whereas a second wave of differentiation occurs from the second heart field (SHF) with a distinct contribution to the four-chambered heart, including the right ventricle (RV), the outflow tract (OFT), and the venous pole (Buckingham et al. 2005). Further subdivisions of the SHF distinguish the contribution of the anterior SHF (aSHF) to the OFT and RV from that of the posterior SHF ( $\mathrm{pSHF}$ ) to the OFT and venous region (Meilhac and Buckingham 2018). Subdivision of the FHF has not been clearly established, but, based on lineage tracing (Bardot et al. 2017), we could wonder whether the FHF can also be patterned along the anteroposterior axis.

Throughout the evolution of vertebrates, the heart has acquired a complex multichambered structure, although conserved FHF and SHF populations can already be identified in tunicates, which are the closest living relatives of an early chordate precursor. Therefore, CPC specification has been studied in different models, ranging from the simple chordate Ciona robusta, which presents a simple beating heart tube, to the mammalian mouse model. Moreover, differentiation of mouse and human pluripotent stem cells ( $m$ - or hPSCs) in vitro into different cardiac lineages has been shown to recapitulate the first steps of CPC specification, including the molecular pathways involved in this process, and are thus an attractive model to determine the minimal cues necessary for the formation of specific cardiac lineages.

In this review, we present currently known markers of early CPCs and their differentiation potential as studied by single-cell approaches. We also discuss insights into the regulation of CPC specification toward specific cardiac or pharyngeal lineages that have recently been discovered through the multiplication of genetic techniques and reduction in costs of next-generation sequencing. Although cardiac neural crest cells also make important contributions to the OFT and valves (Kirby et al. 1983; Kirby and Waldo 1995), we choose here to focus only on the mesodermal contribution to the forming heart.

\section{MARKERS OF EARLY CPCS}

Several key studies have isolated and characterized CPCs and more specifically cardiac progenitors from mouse embryos and differentiating PSCs, which are capable of proliferating and giving rise to multiple cell types of the heart.

As the majority of cardiac and pharyngeal muscle cells derive from the mesoderm, genes that are expressed in the nascent mesoderm such as Brachyury, also called $T$, encoding a T-box transcription factor (TF) (Kispert and Herrmann 1993; Showell et al. 2004) and Mesp1 (mesoderm posterior 1) encoding for a basic helix-loop-helix (bHLH) TF (Saga et al. 1996), are characteristic of early CPCs. Mesp 1 is thereafter rapidly down-regulated once the mesoderm is formed. During differentiation of both $\mathrm{m}$ - and hPSCs, the expression of Mesp1 is also transient and precedes the expression of other cardiac markers (Liu et al. 2007; Ueno et al. 2007; Bondue et al. 2008; Lindsley et al. 2008; Den Hartogh et al. 2015). Mesp1 has spurred great interest in the last two decades as a potential marker of early cardiac progenitor specification of both heart fields (Bondue and Blanpain 2010). Moreover, in the chordate Ciona, Mesp, the unique homolog of Mesp 1 , is expressed transiently in the B7.5 cells pair, which will give rise to the Ciona heart, supporting a conserved role of Mesp genes in CPC specification throughout chordates (Satou et al. 2004).

Specific combinations of surface markers expressed in CPCs can now facilitate their isolation, purification, and characterization. Flk1 (or Vegfr2) and Pdgfra are both expressed in nascent mesoderm (Kataoka et al. 1997; Motoike et al. 2003; Ema et al. 2006). Interestingly, cells coexpressing Flk1 and Pdgfra during differenti- 
Cardiopharyngeal Progenitor Specification

ation of PSCs are enriched for cardiac potential (Hirata et al. 2007). Cxcr4 has also been used in combination with Flk1 (Nelson et al. 2008) or both Flk1 and Pdgfra (Bondue et al. 2011) to isolate CPCs with cardiac potential. The expression of these three signaling receptors coincides with that of Mesp1, and overexpression of Mesp1 directly activates their transcription (Bondue et al. 2011). Flk1/Pdgfra/Cxcr4 also mark early Mesp $^{+}$CPCs in vivo (Lescroart et al. 2014). hPSCs undergoing differentiation into cardiac cell types also necessarily pass through an Flk $1^{+}$mesodermal stage (Yang et al. 2008). Expression of Flk1 and Pdgfra together is generally predictive of CM potential in hPSCs (Kattman et al. 2011). Several other markers have recently been proposed for the isolation of hPSC-derived cardiac progenitors, such as Ror2 and Cd13 (Drukker et al. 2012; Den Hartogh et al. 2015; Skelton et al. 2016), or Fzd4 (Yoon et al. 2018).

One subunit of a chromatin-remodeling complex, Smarcd3, has cardiac-specific expression. Smarcd3 is expressed in a subset of Mesp $1^{+}$ CPCs, and a smaller $2.5-\mathrm{kb}$ regulatory region of this gene can activate reporter gene expression in progenitors for both heart fields in mouse embryos (Devine et al. 2014). Interestingly, the same regulatory region marks zebrafish CPCs, even though this particular sequence was not conserved between both species (Yuan et al. 2018). This suggests that the same core transcriptional regulators are active in CPCs throughout vertebrates and can induce the expression of CPC-specific regulatory regions from other species. As regulatory regions of genes have readily been used to activate reporter gene expression in specific populations of CPCs for the whole heart ( $\mathrm{Wu}$ et al. 2006) or of the SHF (Verzi et al. 2005), the advent of wholegenome predictions of cardiac enhancers and validation of their activity in vivo (He et al. 2011; Yuan et al. 2018) may accelerate the identification of cardiac-specific enhancers expressed as early as during gastrulation in the FHF, SHF, or whole CPF. It would then be interesting to investigate whether these enhancers are specifically active in multipotent pancardiac CPCs or rather independently activated in different lineages.

\section{LINEAGE POTENTIAL OF CPCS}

Although in Ciona the cardiac lineage tree is highly ordered and reproducible, starting from only two Mesp ${ }^{+}$progenitors at the time of gastrulation (Satou et al. 2004), lineage diversification is more complex and plastic in vertebrates, with about $250 \mathrm{Mesp}^{+}$progenitors contributing to the heart in the mouse model (Chabab et al. 2016).

The first experiments assessing the lineage potential of CPCs were performed in the chick and the mouse, using dye labeling or grafting experiments (Stalsberg and DeHaan 1969; Tam and Behringer 1997; Kinder et al. 1999; Lawson 1999; Tzahor et al. 2003). Grafting experiments have shown that cardiac progenitors are committed to a cardiac fate only after the formation of the cardiac crescent (Tam and Behringer 1997; Auda-Boucher et al. 2000), suggesting a certain degree of plasticity of CPCs at gastrulation stages.

Lineage tracing experiments, clonal analyses, and, more recently, single-cell RNA-sequencing (scRNA-seq) have allowed us to decipher the appearance of different cell lineages that arise from early CPCs.

Lineage Tracing and In Vitro Differentiation Demonstrates the Multipotency of CPCs

Lineage tracing experiments with a Flk1-Cre knockin mouse model showed that although originally involved in hematopoietic lineages, Flk $1^{+}$cells also contribute to the development of CMs and ECs (Motoike et al. 2003; Ema et al. 2006). Furthermore, during differentiation of PSCs, $\mathrm{T}^{+} / \mathrm{Flk}^{+}$cells present the ability to form colonies comprising CMs, SMCs, and ECs, suggesting that this early mesodermal cell population is at least tripotent (Kattman et al. 2006). Tracking the progeny of Mesp1-expressing cells revealed that they comprise the majority of cardiac cells including CM, ECs, and EPDCs (Saga et al. 1999). In addition, the Mesp1 lineage also contributes to noncardiac derivatives, including skeletal muscles of the head and neck (see Table 1; McBratney-Owen et al. 2008; Yoshida et al. 2008; Asahina et al. 2009; Harel et al. 2009). 
B. Swedlund and F. Lescroart

Table 1. Lineage tracing in mouse has revealed the existence of different early CPC subpopulations

\begin{tabular}{|c|c|c|c|c|c|}
\hline $\begin{array}{l}\text { CPC } \\
\text { subpopulation }\end{array}$ & $\begin{array}{c}\text { Genetic } \\
\text { construct used }\end{array}$ & $\begin{array}{l}\text { Labeled } \\
\text { cardiac } \\
\text { regions }\end{array}$ & $\begin{array}{l}\text { Labeled } \\
\text { cardiac cell } \\
\text { types }\end{array}$ & $\begin{array}{c}\text { Noncardiac } \\
\text { derivatives }\end{array}$ & Reference(s) \\
\hline$M e s p 1^{+}$ & $\begin{array}{l}\text { Mesp1-Cre; } \\
\quad \text { R26R }\end{array}$ & $\begin{array}{r}\text { OFT, RV, } \\
\text { LV, RA, } \\
\text { LA, IFT }\end{array}$ & $\begin{array}{l}\text { SMCs, ECs, } \\
\text { CMs, } \\
\text { EPDCs }\end{array}$ & $\begin{array}{l}\text { Some head bones and } \\
\text { head muscles, dorsal } \\
\text { aorta, intersomitic } \\
\text { and cranial vessels, } \\
\text { hematopoietic } \\
\text { progenitors, amion, } \\
\text { mesothelial cells of } \\
\text { the liver }\end{array}$ & $\begin{array}{l}\text { Saga et al. 1999; } \\
\text { McBratney-Owen } \\
\text { et al. 2008; Yoshida } \\
\text { et al. 2008; Asahina } \\
\text { et al. 2009; Harel et al. } \\
\text { 2009; Lescroart et al. } \\
2014\end{array}$ \\
\hline $\operatorname{Smarcd} 3^{+}$ & $\begin{array}{l}\text { Smarcd3- } \\
\qquad \text { F6-CreERT2; } \\
\text { R26R (Tam } \\
\text { E6.5) }\end{array}$ & $\begin{array}{l}\text { OFT, RV, } \\
\text { LV, RA, } \\
\text { LA }\end{array}$ & ECs and CMs & Anterior forelimb & Devine et al. 2014 \\
\hline Foxa $^{+}$ & $\begin{array}{l}\text { Foxa2-Cre; } \\
\quad \text { R26R- } \\
\text { tdTomato }\end{array}$ & $\mathrm{RV}, \mathrm{LV}$ & $\begin{array}{c}\text { CMs, ECs, } \\
\text { EPDCs }\end{array}$ & Endoderm derivatives & Bardot et al. 2017 \\
\hline Mef2c-AHF-enh ${ }^{+}$ & $\begin{array}{c}M e f 2 c-A H F- \\
\text { enh-Cre; } \\
\text { R26R }\end{array}$ & $\begin{array}{l}\text { OFT, RV, } \\
\quad \text { IS }\end{array}$ & $\begin{array}{l}\text { CMs, ECs, } \\
\text { SMCs }\end{array}$ & Head muscles & $\begin{array}{l}\text { Verzi et al. 2005; } \\
\text { Lescroart et al. 2010; } \\
\text { Devine et al. } 2014\end{array}$ \\
\hline $\mathrm{Hcn}^{+}$ & $\begin{array}{l}\text { Hcn4-CreERT2; } \\
\text { R26R (Tam } \\
\text { E6.-E7.0) }\end{array}$ & LV & $\mathrm{CMs}$ & Cardiac specific & Liang et al. 2013 \\
\hline Hand $1^{+}$ & $\begin{array}{l}\text { Hand1-Cre; } \\
\quad \text { R26R }\end{array}$ & OFT, LV & CMs, EPDCs & $\begin{array}{l}\text { Postmigratory NCCs, } \\
\text { forelimb and } \\
\text { hindlimb } \\
\text { mesenchyme }\end{array}$ & Barnes et al. 2010 \\
\hline Sfrp $5^{+}$ & Sfrp5-Cre; R26R & $\begin{array}{l}\text { OFT, LV, } \\
\text { RA, LA }\end{array}$ & $\begin{array}{l}\text { CMs, ECs, } \\
\text { EPDCs }\end{array}$ & Not determined & Fujii et al. 2017 \\
\hline $\operatorname{Six}^{+}$ & $\begin{array}{l}\text { Six2-Cre-ERT2; } \\
\quad \text { R26R }\end{array}$ & OFT, RV & SMCs, CMs & $\begin{array}{l}\text { Head muscles, } \\
\text { urogenital tissues }\end{array}$ & Zhou et al. 2017 \\
\hline $\operatorname{Hoxb1}^{+}$ & $\begin{array}{l}\text { Hoxb1-Cre; } \\
\quad \text { R26R }\end{array}$ & $\begin{array}{l}\text { OFT, RA, } \\
\text { LA }\end{array}$ & CMs, ECs & $\begin{array}{l}\text { Large contribution to } \\
\text { the endoderm and } \\
\text { mesoderm }\end{array}$ & Bertrand et al. 2011 \\
\hline
\end{tabular}

Summary of the results obtained after lineage tracing of different CPC subpopulations.

(CPC) Cardiopharyngeal progenitor cell, (OFT) outflow tract, (RV) right ventricle, (LV) left ventricle, (RA) right atrium, (LA) left atrium, (IFT) inflow tract, (CMs) cardiomyocytes, (ECs) endothelial/endocardial cells, (SMCs) smooth muscle cells, (EPDCs) epicardium-derived cells, (NCC) neural crest cell, (IS) interventricular septum.

Interestingly, this observation seems consistent with findings in Ciona, where Mesp ${ }^{+}$cells also produce the anterior and tail muscles, indicating their multipotency (Fig. 1; Stolfi et al. 2010). During mouse and hPSC differentiation, isolated Mesp1-expressing cells have the potential to become ECs, SMCs, and CMs in a clonal assay (Bondue et al. 2011; Den Hartogh et al. 2015). Furthermore, an in vitro clonal assay using
mPSCs demonstrated the bipotential of $M e s p 1^{+}$cells to generate skeletal and cardiac muscles, in agreement with their broad fate potential in vivo (Chan et al. 2016).

Additional PSC studies have further shown that cardiac progenitors from slightly later stages, when Nkx2-5 is coexpressed with other markers such as the TF Isl1, are able to generate colonies with the potential to give rise to two or 


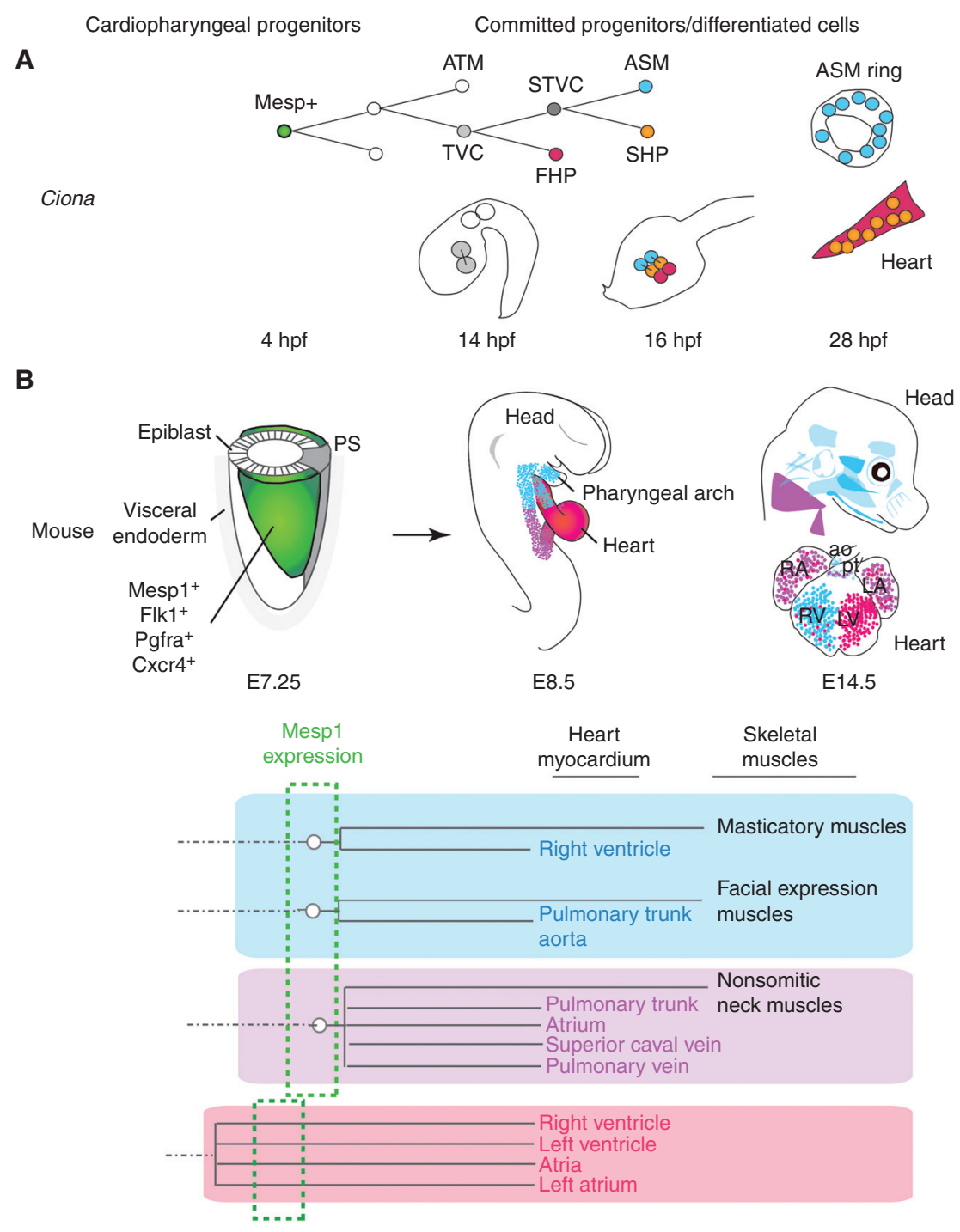

Figure 1. Steps from cardiopharyngeal progenitor cells (CPCs) to cardiac and skeletal muscle cell lineages: comparison between tunicates and mouse. (A) The Ciona CPC lineage tree is found on top. Two Mesp ${ }^{+}$CPCs (green) are found at $\sim 4$ hours postfertilization (hpf). After two cell divisions, these CPCs form four anterior tail muscle (ATM) cells and four multipotent trunk ventral cells (TVCs). These TVCs divide asymmetrically to form a second TVC (STVC) and a first heart precursor ([FHP], red). The STVC (dark gray) divides to form an atrial siphon muscle ([ASM], blue) progenitor cell, analogous to the vertebrate head muscles and a second heart precursor ([SHP], orange). A subset of the lineage branches is depicted from a single Mesp CPC, the other branches being identical in sequence and outcome. (Below) Layout of the tunicate larva. Black lines indicate sister cells. Time after fertilization is indicated in hpf. At $\sim 28 \mathrm{hpf}$, ASM progenitor derivatives form an ASM ring, whereas FHP- and SHP-derived cells form the developing heart, including pericardial cells and cardiomyocytes. (B) The mouse CPC lineage. On top, early CPCs (in green) are found in the gastrulating embryo and are marked by the expression of Mesp1, Flk1, Pdgfra, and Cxcr4 as soon as they leave the primitive streak (PS). At embryonic day (E) 8.5, the primary heart tube is mainly formed from first heart field ([FHF], red) progenitors, with additional contribution to the arterial and venous pole, respectively, from anterior and posterior second heart field ([aSHF], blue, and [pSHF], purple, respectively) progenitors that lie behind the heart tube, within the cardiopharyngeal mesoderm. On the right, the contribution of FHF and anterior and posterior pharyngeal mesoderm to the head and neck muscles and to the heart; below, the lineage tree deduced from retrospective clonal analysis. Interestingly, there are at least three reiterations of the Ciona ontogenetic motif along the anteroposterior axis of the embryo. The expression window of Mespl is indicated by green dotted lines. Mesp1 is first expressed in the FHF progenitors (red), and expressed later in the anterior (blue) and posterior (purple) progenitors of the cardiopharyngeal field. (EOMs) Extraocular muscles, (ao) aorta, (pt) pulmonary trunk, (RA) right atrium, (LA) left atrium, (RV) right ventricle, (LV) left ventricle. 
three cardiac cell types (Moretti et al. 2006; Wu et al. 2006). Therefore, early CPCs are multipotent and plastic. Nevertheless, we will discuss below that they are also specified very early toward a certain fate, and that when left in their endogenous environment, they are mostly uniproductive and contribute to specific cardiac regions and cell types.

\section{Single Cells Analyses Reveal Heterogeneity among CPCs}

Single-cell analyses have considerably changed our vision of CPC specification and have shown that the differential contribution of CPCs in the mouse model is complex, with many branching points and possible outcomes.

The first clonal analyses performed in mouse, using retrospective clonal analysis, demonstrated the existence of two myocardial cell lineages, corresponding to the FHF and SHF. On the basis of the number of $\beta$-gal ${ }^{+}$cells included in clones covering both lineages, lineage segregation between the first and second myocardial lineages was estimated to occur at the onset of gastrulation (Meilhac et al. 2004). More recent clonal tracing of $\mathrm{Mesp}^{+} \mathrm{CPCs}$ using two independent strategies (Mesp1-rtTA/ tetO-Cre/Rosa-Confetti or an Mesp1-Crel $M A D M$ system) established that lineage segregation of the FHF and SHF occurs before the onset of Mesp1 expression, as shown by the absence of clones in both FHF and SHF derivatives (Devine et al. 2014; Lescroart et al. 2014). Similarly, clonal tracing of Smarcd $3^{+}$progenitors showed no evidence of a common progenitor for the FHF and SHF (Devine et al. 2014).

As in tunicates, multipotent progenitor cells giving rise to the $\mathrm{SHF}$ in the mouse also generate skeletal muscles of the head and neck, with at least three different populations of bipotent progenitors found along the anteroposterior axis of the pharyngeal region, contributing to the masticatory muscles and RV, facial expression muscles, and OFT or neck muscles and venous pole as well as OFT myocardium (Fig. 1; Lescroart et al. 2010, 2015). Furthermore, Mesp1 lineage tracing also identified clones labeling both skeletal muscles of the head and the myocardium, suggesting that segregation between cranial and cardiac muscles occurs after the onset of Mesp1 expression (Lescroart et al. 2014). Nevertheless, most $\mathrm{Mesp}^{+} \mathrm{CPCs}$ are uniproductive and contribute in the heart to either the epicardium, CMs, SMCs, or ECs, with only a few bipotent Mesp1-derived clones contributing to CMs and ECs, or SMCs and CMs, and only in SHF derivatives (Devine et al. 2014; Lescroart et al. 2014).

The heterogeneity of CPCs is exemplified by the different genetic lineage tracing experiments that have been performed and that label different compartments of the heart (Table 1; Meilhac and Buckingham 2018). For example, Foxa2 ${ }^{+}$ cells, found very early during gastrulation, preferentially contribute to the ventricles and epicardium. Interestingly, Foxa $2^{+}$cells seem to express lower levels of Mesp1 (Bardot et al. 2017). Tracing with a particular enhancer of $M e f 2 c$, activated during gastrulation, labels only a subpopulation of cardiac tissue and specifically aSHF derivatives, comprising the OFT and RV, as well as some head muscles (Verzi et al. 2005; Lescroart et al. 2010; Devine et al. 2014). The anterior Hox genes (Hoxa1, Hoxa3, Hoxb1) distinguish pSHF progenitors with contributions to the inferior wall of the OFT and atria (Bertrand et al. 2011). Hand $1^{+}$cells only contribute to the CM of the LV (Barnes et al. 2010). Similarly, early Hcn4-expressing cells contribute specifically to the cardiac crescent and subsequently to LV CMs (Liang et al. 2013; Spater et al. 2013). Interestingly, Sfrp5, which encodes a secreted receptor for Wnt signaling, is expressed in progenitors of all cardiac regions including CMs, ECs, and EPDCs, with the exception of the RV (Fujii et al. 2017).

In addition, there is also clearly a dynamic temporal expression of markers during CPC specification such that CPCs expressing Mesp1 at different time points during gastrulation will have different contributions to the heart and head. Temporally controlled clonal analysis of $M e s p 1^{+}$CPCs has thus shown that LV progenitors express Mesp1 early (induced with doxycycline at E6.25), whereas the OFT, RV, and atria and head muscles derive preferentially from CPCs that express Mesp1 slightly later (induced at E7.25) (Lescroart et al. 2014). Similarly, clonal 
analysis using a Six2-Cre-ERT2 line revealed that Six2 is expressed in a subset of late CPCs and that Six 2 is successively activated in different populations of CPCs that contribute to the RV (induction with tamoxifen at E6) and then to the OFT (induction at E7.5) together with head muscles (Zhou et al. 2017). Interestingly, inducible lineage tracings of $\mathrm{Hcn}^{+}, \mathrm{Tb}_{x} 5^{+}$, or $\mathrm{Sma}^{+}$ (smooth muscle actin, expressed in embryonic CMs) show a progressive contribution of cardiac progenitors to the heart with early differentiating cells contributing specifically to the left side of the interventricular septum (Spater et al. 2013; Devine et al. 2014; Choquet et al. 2016).

Finally, with the emergence of new technologies such as high-throughput scRNA-seq, it is now possible to study the heterogeneity of CPCs in detail as they arise and specify to a cardiac or muscular fate during gastrulation. A first study by Chan et al. (2016) applied scRNA-seq to $M \operatorname{esp} 1^{+}$mPSCs during differentiation and revealed the existence of at least six subpopulations of $\mathrm{Mesp}^{+}$progenitors, with some primed for hematopoietic lineages, whereas others were primed toward the cardiac lineages. Single-cell expression profiling of nascent mesoderm at the late stage of mouse gastrulation demonstrated the existence of distinct populations of cardiac progenitors with different states of expression of Mesp1, Tbx5, Nkx2-5, and Isl1 (Kokkinopoulos et al. 2015). scRNA-seq of Mesp $1^{+}$CPCs in vivo (from E6.75 to E7.25) has shown a continuum of cell states along distinct cardiopharyngealrelated trajectories toward four destination cell types. These distinct trajectories likely correspond to CMs, ECs, anterior CPF (including $\mathrm{aSHF}$ ) or posterior CPF (including pSHF) lineages, with different markers enriched in these different populations. RNA-fluorescent in situ hybridization (FISH) using specific markers of these four types further demonstrated that these populations of prespecified CPCs have distinct spatial localization in the gastrulating embryo (Fig. 2). EC-primed $\mathrm{Mesp}^{+}$progenitors are found in the outer layer of mesodermal cells, in the vicinity of the visceral endoderm, whereas CM-primed $\mathrm{Mesp}^{+}$progenitors are found closer to the epiblast. aSHF and pSHF-Mesp $1^{+}$markers were largely nonoverlapping, with $W n t 2 b$ (pSHF marker) being expressed close to the PS and FoxC2 (aSHF marker) being expressed more anterolaterally (Fig. 2; Lescroart et al. 2018). Tcf21, which labels cardiopharyngeal progenitors that contribute to head muscle formation, is expressed in the anterior CPF population.

In Ciona, the two Mesp ${ }^{+}$progenitors divide once in the early gastrula to give rise to four equivalent multipotent progenitors, which then divide asymmetrically at the end of gastrulation to generate anterior tail muscle (ATM) progenitors and trunk ventral cells (TVCs). Cardiac cells (CMs and pericardial cells) derive from TVCs (Davidson et al. 2005, 2006; Beh et al. 2007; Christiaen et al. 2008). TVCs are multipotent progenitors that divide asymmetrically a second time to form first heart precursors (FHPs) and second TVCs (STVCs) (Stolfi et al. 2010). STVCs divide asymmetrically again to form lateral atrial siphon muscle founder cells (ASMFs) and second heart precursors (SHPs) (Fig. 1; Stolfi et al. 2010; Wang et al. 2013). scRNA-seq of progenitor cells covering the early branches of the cardiopharyngeal lineage tree in Ciona intestinalis identified three distinct transcriptional clusters that correspond to the cardiac FHP and SHP populations as well as an $\mathrm{Ebf}^{+}$pharyngeal muscle population. Interestingly, this analysis showed that specific transcriptional programs are activated in fatecommitted progenitors. In addition, this single-cell transcriptomic study identified new specific-lineage markers, including $M m p 21$ for the FHP and Dach as an SHP-specific marker. Remarkably, in the mouse, Dach1 is first broadly expressed in pharyngeal mesoderm and then also restricted later to cardiac SHF progenitors (Wang et al. 2019).

Although single-cell approaches have helped us investigate in more detail the heterogeneity of the CPC population at different stages of development mostly through gene expression, the combination of these techniques with rapidly advancing systems approaches to functional genomic analysis (single-cell CITE-seq, single-cell ATAC-seq) will further improve our understanding of the molecular mechanisms implicated in early cell fate decisions. 


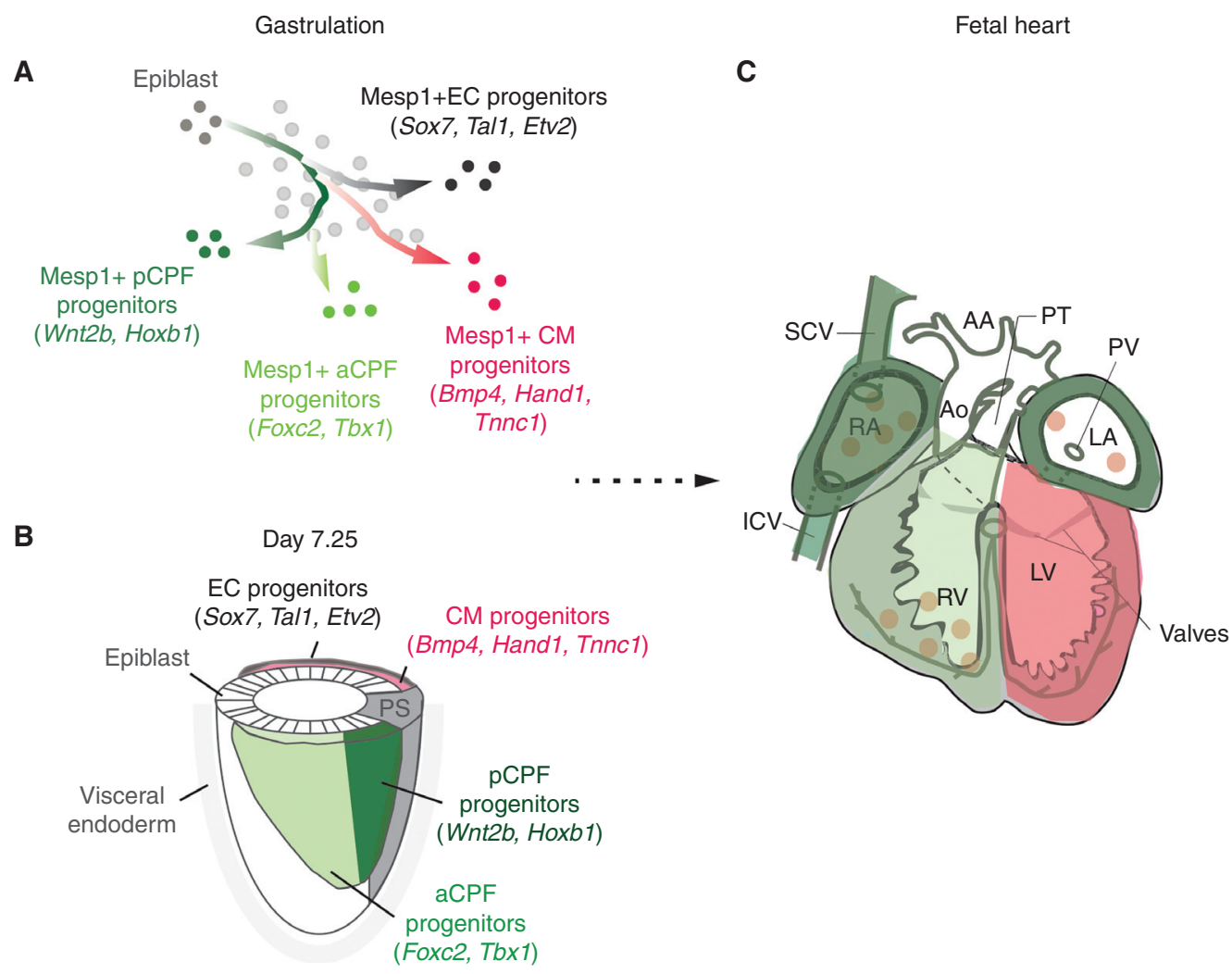

Figure 2. Heterogeneity of cardiopharyngeal progenitor cell (CPC) specification as revealed by single-cell analysis. (A) In single-cell RNA-sequencing (scRNA-seq) experiments, four distinct Mesp $1^{+} \mathrm{CPC}$ subpopulations have been identified that emerge from epiblast cells and that correspond to the endothelial/endocardial cell ([EC], black), cardiomyocyte ([CM], red), anterior cardiopharyngeal field ([aCPF], light green), and posterior CPF ( pCPF, dark green) progenitors. These populations are enriched for some transcripts (in parentheses) and are found in particular locations in the embryo $(B) .(B)$ Drawing of the gastrulating embryo, where the different CPC subpopulations are found. The embryo is bilateral; on one side is depicted the localization of the Mesp $1^{+} \mathrm{EC}$ versus $\mathrm{Mesp}^{+} \mathrm{CM}$ populations found either in the outer layer or close to the epiblast, whereas on the other side the localization of aCPF and pCPF progenitors is represented along the anteromedial axis of the embryo. These distinct CPC subpopulations make different regional contributions to the definitive heart $(C)$. (AA) Aortic arch, (PT) pulmonary trunk, (Ao) aorta, (PV) pulmonary vein, (SCV) superior caval vein, (ICV) inferior caval vein, (RA) right atrium, (LA) left atrium, (RV) right ventricle, (LV) left ventricle.

\section{REGULATION OF CPC SPECIFICATION}

\section{Early Induction of Cardiogenic Mesoderm}

The extrinsic signals given to cells during development in vivo can be used as guidance cues during PSC differentiation from pluripotency toward specific cell types. It is therefore important to understand the stage-specific requirements of signaling pathways and their downstream TFs during early differentiation (Noseda and Schneider 2010; Loh et al. 2016).
CPCs arise from epiblast cells that form the primitive streak (PS). Their specification therefore depends on correct positioning and formation of the PS; this process relies on several signaling pathways, including canonical Wnt/ $\beta$ catenin and Tgf $\beta /$ Nodal pathways (Conlon et al. 1994; Haegel et al. 1995; Noseda and Schneider 2010). The same pathways are required to induce formation of PS-like cells and subsequent cardiogenic mesoderm from PSCs (Xu et al. 1999; Gadue et al. 2006). Canonical Wnt signal- 
ing has a biphasic role during cardiogenesis, as it promotes early steps of cardiogenesis but then inhibits CM differentiation (Marvin et al. 2001; Schneider and Mercola 2001; Tzahor and Lassar 2001; Naito et al. 2006; Liu et al. 2007; Qyang et al. 2007; Ueno et al. 2007; Paige et al. 2010). Bone morphogenetic protein (BMP) signaling is also required for subsequent gastrulation and formation of the cardiac crescent (Mishina et al. 1995; Miura et al. 2006). The requirement of these signaling pathways for cardiac development is well conserved throughout chordates (Noseda and Schneider 2010). Modulation of these pathways and others has guided most protocols of differentiation of PSCs toward cardiac lineages (Laflamme et al. 2007; Yang et al. 2008; Kattman et al. 2011). Briefly, formation of cardiac mesoderm can be induced from PSCs by BMP4, Vegf, Activin A, and Fgf2, and subsequent differentiation is enhanced by Wnt inhibition. These are the minimal requirements for the formation of cardiac lineages in vitro in serum-free conditions. These extrinsic signals induce an intrinsic cascade of molecular events, in which the activation of core transcriptional regulators thereafter progressively promotes cardiac cell fates during differentiation. We will now discuss these intrinsic events.

In Drosophila, tinman, the ortholog of $N k \times 2-5$, is considered to be the master regulator of cardiogenesis (Azpiazu and Frasch 1993; Bodmer 1993; Frasch 1995). Whereas mutations in $N k x 2-5$ are associated with congenital heart disease (Schott et al. 1998), Nkx2-5 mouse mutants form an early heart tube (Lyons et al. 1995; Tanaka et al. 1999) showing that during evolution, Nkx2-5 lost its central role in cardiac specification, likely as a result of the expansion of the vertebrate $N k x$ gene family. A key role for Mesp1 has clearly been established for cardiac specification in chordates (Saga et al. 2000; Bondue and Blanpain 2010; Liu 2017). Mesp1 mutant mouse embryos present cardia bifida, with differentiated CMs and ECs in separated heart fields (Saga et al. 1999). Double mutants for Mesp1 and its closest homolog, Mesp2, on the other hand, have severe defects of gastrulation. Chimeras with Mesp1/2 null and wild-type cells showed contributions of mutant cells to most of the embryo excluding the heart, indicating a cell-autonomous requirement of Mesp1/2 for CPC specification (Kitajima et al. 2000). Mesp1 $1^{\mathrm{Cre} / \mathrm{Cre}}$ knockout cells present a developmental block similar to that of double-mutant embryos, with mesodermal precursors being stuck in the gene program of the epiblast, as shown by scRNA-seq. Transcripts of several regulators of pluripotency such as Nanog, Oct4, and Eras or markers of the epiblast including E-cadherin and Epcam, were thus up-regulated in Mesp1-null cells (Lescroart et al. 2018).

Interestingly, during mPSC differentiation, overexpression of human or murine Mespl accelerates and increases cardiac differentiation, as shown by the appearance of beating areas and enhanced troponin $\mathrm{T}$ expression (Bondue et al. 2008; David et al. 2008; Lindsley et al. 2008). However, continuous expression of Mesp1 inhibits cardiac differentiation (Bondue et al. 2008). Mesp1 has been shown to directly bind to the promoter of key cardiac TFs, such as Mef2c, Tbx20, Gata4, and Nkx2-5, thereby upregulating their expression and promoting further up-regulation of downstream cardiac genes (Fig. 3). Nevertheless, in the context of reprogramming, forced Mesp 1 expression in cardiac fibroblasts is not sufficient to induce cardiac specification. In contrast, Smarcd3, Tbx5, and Gata4 have been shown to be sufficient for cardiac reprogramming (Takeuchi and Bruneau 2009; Ieda et al. 2010).

The key role of Mesp genes during cardiac progenitor specification appears to be highly conserved in chordates, as shown by the induction of ectopic cardiac differentiation upon expression of a constitutive form of Mesp ortholog in Ciona and human Mesp1 in Xenopus (Davidson et al. 2005; David et al. 2008). Knockdown experiments using morpholinos also demonstrated the importance of Mesp for cardiac specification in ascidians (Satou et al. 2004). In fish, the master regulator role of Mesp is not clear. Although there are four mesp genes, only mespaa has a procardiogenic role after animal cap transplants with mespaa overexpressing cells. Surprisingly, mespaa or even quadruple mespaa/ab/ba/bb CRISPR/Cas9 mutants did not show any cardiac defects (Deshwar et al. 2016). 


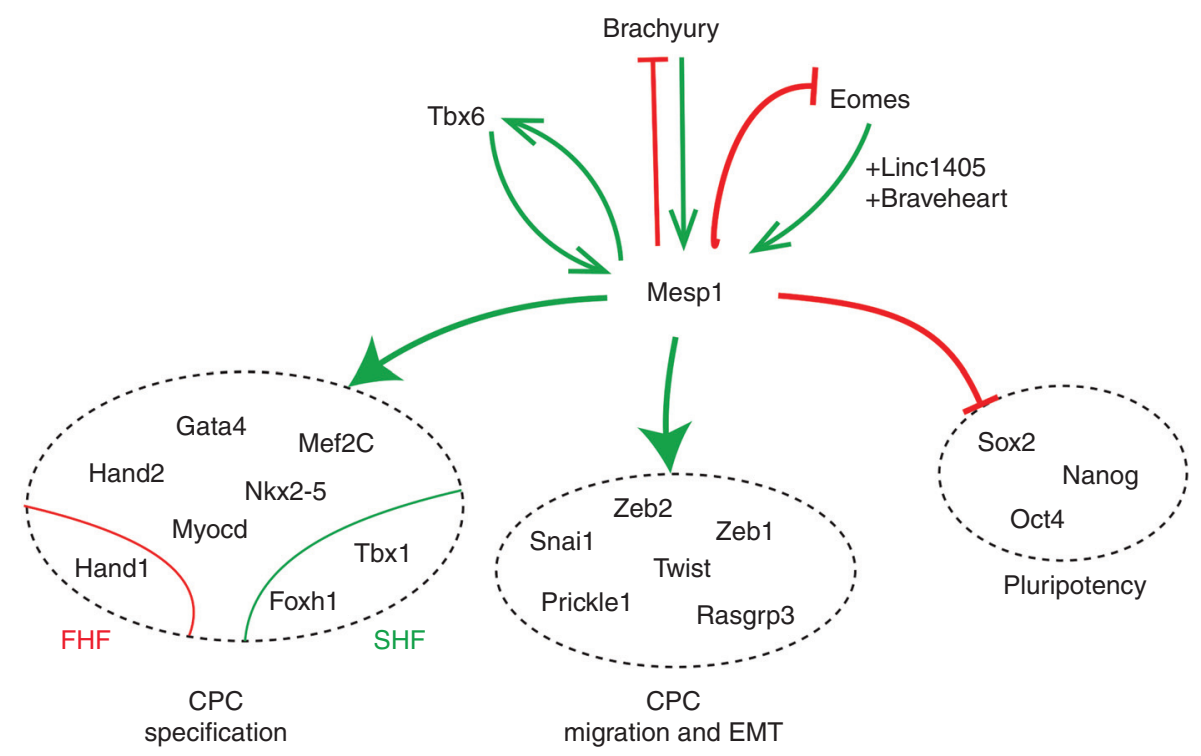

Figure 3. Early intrinsic regulation of cardiac specification. Representation of the molecular hallmarks of cardiac progenitor cell commitment. When cardiac progenitors express Mesp1 in the nascent mesoderm, they turn off the genetic program of pluripotency and turn on the gene regulatory network of cardiac specification and migration. Green arrows represent direct activation; red arrows represent repression. Genes grouped together are regulated in a similar manner by Mesp1. Although Linc1405 was shown to interact with Eomes, it was not the case for Braveheart, another cardiogenic long noncoding RNA. (FHF) First heart field, (SHF) second heart field, (CPC) cardiopharyngeal progenitor cell, (EMT) epithelial-to-mesenchymal transition.

Mesp1 is activated in nascent mesoderm by key regulators of endoderm and mesoderm development Eomesodermin (Tbr2) and Brachyury (T) (Costello et al. 2011; David et al. 2011; van den Ameele et al. 2012). In Ciona embryos, Mesp is activated by Tbx6 and Lhx3, only in B7.5 cells coexpressing these factors (Davidson et al. 2005; Christiaen et al. 2009). Consistent with these findings, a recent report searching for mesoderm-inducing factors in mouse embryonic fibroblasts found that Tbx6 was sufficient to activate Mesp1 and subsequent CPC gene expression. During PSC differentiation, Tbx6 promoted mesoderm and endoderm induction in the absence of serum and growth factors in both a cell-autonomous and non-cell-autonomous manner (Sadahiro et al. 2018). Further studies in mouse will be required to determine how the precise domain of Mespl expression is defined within the nascent mesoderm, although other factors are also implicated in early specification of cardiac progenitors, such as long noncoding RNAs (Klattenhoff et al. 2013; Ounzain et al. 2015; Guo et al. 2018), which have even been used to promote transdifferentiation to cardiac cell types (Fig. 3; Hou et al. 2017).

Finally, the dynamic gene expression changes involved in transitions from pluripotency to cardiogenic mesoderm are accompanied by modifications of the epigenetic landscape or chromatin accessibility, with regulatory regions of genes being first primed then activated, and other regions involved in alternative fates being decommissioned (Paige et al. 2012; Wamstad et al. 2012; Racioppi et al. 2019). TFs cooperate to induce these changes, through interactions with each other and specific chromatin modifiers (Chang and Bruneau 2012; Luna-Zurita et al. 2016). Combining data from single-cell expression and broad epigenetic studies, such as repressive histone mark ChIP-seq data from many tissues, may help us to identify new genetic drivers of cell fate specification (Shim et al. 2019). 
CPC Specification to the Different Cardiac Lineages

In vitro, mPSCs cultured in serum conditions can form three populations with differential expression of T and Flk1 (Kouskoff et al. 2005; Kattman et al. 2006). Hemangioblast specification usually precedes cardiac specification, as the former derives from a first wave of Flk1expresssing Brachyury ${ }^{+}$cells, whereas the cardiogenic mesoderm arises from a Brachyury ${ }^{+}$ population, with later expression of Flk1 (Kattman et al. 2006). Interestingly, if Mesp1 is induced earlier during mPSC differentiation, there is an increase in the hematopoietic progenitor population through direct activation of Tal1, encoding a vascular TF, at the expense of cardiac fates (Chan et al. 2013). Conversely, in the absence of Tal1, extraembryonic tissue (also expressing Mesp1) can differentiate into CMs (Van Handel et al. 2012).

CM and EC lineages of the FHF segregate early during gastrulation (Mikawa and Fischman 1996; Wei and Mikawa 2000; Lescroart et al. 2014). scRNA-seq of Mesp $1^{+}$CPCs showed that several Notch signaling actors, including Notch1, are specifically down-regulated in CM-fated cells and conversely up-regulated in EC-fated cells (Lescroart et al. 2018). The Notch pathway has been implicated in several key processes of cardiac development, including trabeculation and valve formation (MacGrogan et al. 2010, 2018). In vitro activation of Notch reduces CM differentiation (Nemir et al. 2006) and repression of Notch increases CM differentiation (Schroeder et al. 2003). Lineage tracing of early Notch $1^{+}$cells preferentially marks the endocardium, suggesting a potential role for the Notch pathway in early CPC fate decisions between CMs and ECs (Lescroart et al. 2018). Moreover, further cross talk between these two lineages happens in vitro and in vivo, suggesting paracrine mechanisms governing CPC specification and differentiation (Saba et al. 2019; Saint-Jean et al. 2019). Interestingly, ECs with "valve-like" properties can be derived from hPSCs through the activation of other signaling pathways. Vascular endothelial growth factor (VEGF), together with FGF2 and FGF8, can induce EC differentiation at the expense of CMs, thus favoring the specification of a prevalvular cell type (Neri et al. 2019).

The PSC model has also been used to specify PSCs into other cardiac cell lineages (Fig. 4). Epicardial cells, for example, can be produced from hPSCs. Indeed, stage-specific activation of $\mathrm{BMP}$, retinoic acid (RA), and $\mathrm{Wnt} / \beta$-catenin signaling pathways after induction of CPCs induces the specification of epicardial-like progenitors expressing TBX18 and WT1, two markers of the proepicardial organ (Iyer et al. 2015; Bao et al. 2016; Guadix et al. 2017). In line with these findings, mouse embryos lacking the Wnt inhibitors Dkk1 and Dkk2 have a thicker epicardium and thinner myocardium (Phillips et al. 2011), showing again the necessity and usefulness of translating our current in vivo knowledge for in vitro generation of specific cell types. Epicardial cells can differentiate into cardiac fibroblasts or vascular SMCs through epithelial-to-mesenchymal transition, which can be induced in vitro by addition of Tgf- $\beta 1$ to the cells. Nevertheless, as the epicardium gives rise to multiple cell lineages, the resulting cell population is heterogeneous. To obtain a pure population of cardiac fibroblasts without going through an epicardial-like stage, another protocol has recently been developed in which activation of the FGF pathway in hPSC-derived CPCs induces formation of periostin- and vimentinexpressing cardiac fibroblasts, presenting many functional similarities with their in vivo counterparts (Zhang et al. 2019).

Pacemaker CMs can also be generated from mPSC by induction of Tbx3 (Jung et al. 2014) or Shox2 (Ionta et al. 2015). Sinoatrial node (SAN)like pacemaker cells arise from $\mathrm{Nkx} 2.5^{-}, \mathrm{Tbx} 18^{+}$ CPCs (Mommersteeg et al. 2010). As a first demonstration of generating SAN-like pacemaker cells from hPSCs without recurring to overexpression, inhibition of the FGF pathway with activation of BMP and RA signaling generated a NKX2-5- but SIRPA ${ }^{+}$cardiac cell type, presenting pacemaker properties similar to SAN cells. These cells were able to display pacemaker activity when grafted into rat hearts (Protze et al. 2017). 


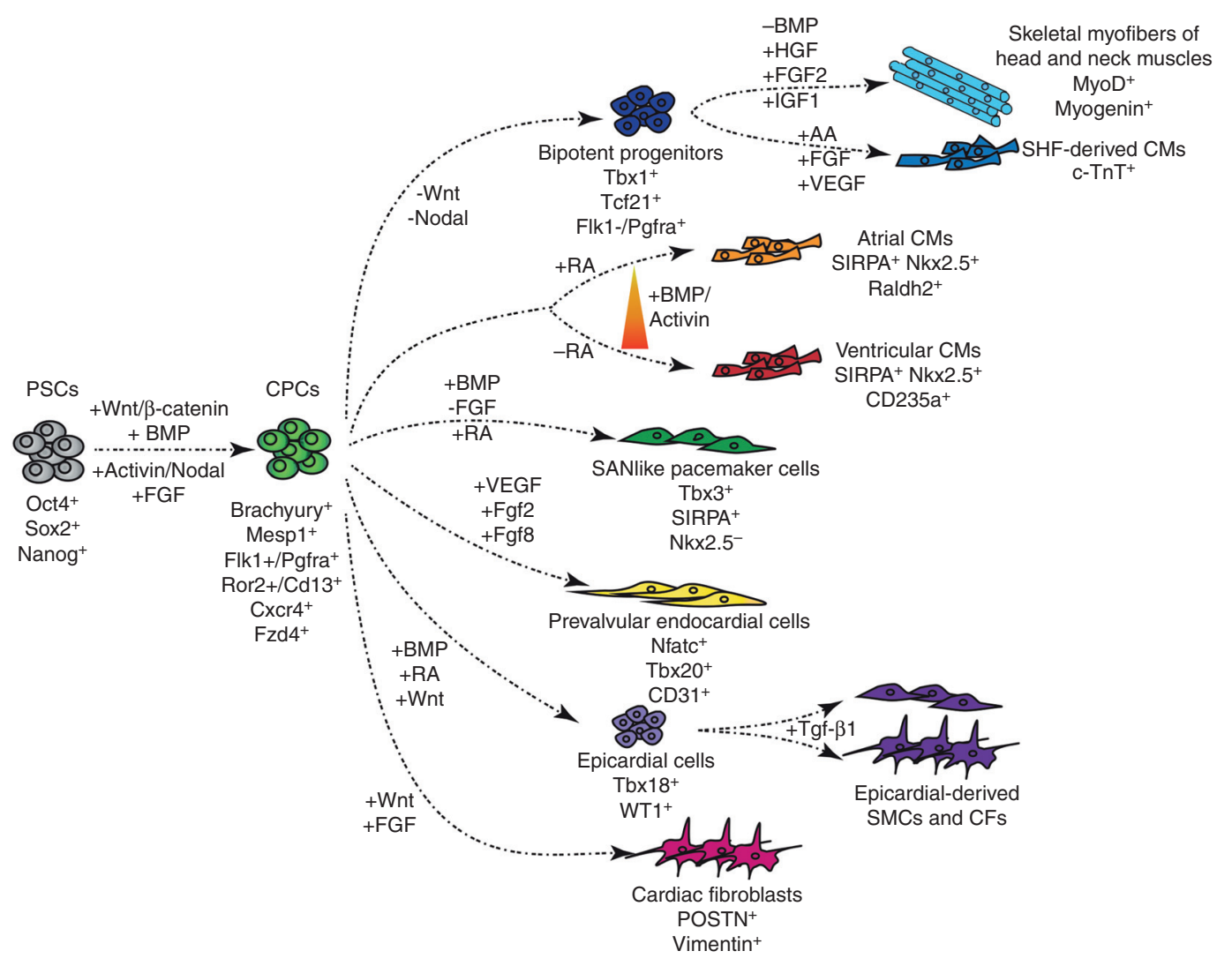

Figure 4. Extrinsic regulation of cardiac specification. By differentiating mouse and human pluripotent stem cells (PSCs) under serum-free conditions, the minimal cues necessary for their specification and differentiation to a particular cardiopharyngeal cell lineage were defined. Arrows indicate different steps of differentiation. All protocols pass through a stage in which cells present features of multipotent cardiopharyngeal progenitor cells (CPCs), then diverge in terms of given signaling modulators and cell markers. (AA) Ascorbic acid, (BMP) bone morphogenetic protein, (CFs) cardiac fibroblasts, (CMs) cardiomyocytes, (FGF) fibroblast growth factor, (IGF-1) insulin-like growth factor-1, (HGF) hepatocyte growth factor, (SAN) sinoatrial node, (SHF) second heart field, (SMCs) smooth muscle cells, (VEGF) vascular endothelial growth factor.

\section{Regional Specification}

Multiplication of the cardiac chambers has significantly increased the efficiency but also complexity of the heart during evolution. The specification of early CPCs toward a particular cardiac region is not yet fully understood and there may be a lot to glean from in vitro PSC models and in vivo studies.

One of the main regional distinctions is between atrial and ventricular cardiac tissue. As discussed previously, lineage-tracing experiments in the mouse have shown the existence of distinct CPCs that contribute to different cardiac regions. For example, Foxa $2^{+}$CPCs specifically label ventricular derivatives. Formation of chimeric embryos from wild-type and Foxa2 ${ }^{-/-}$ mutant mPSCs have shown that Foxa2 is cellautonomously required for ventricular specification such that there is no contribution of mutant cells to the ventricles. Similarly, Foxa2 ${ }^{-1-}$ mPSCs have a decreased ability to form ventricular CMs (Bardot et al. 2017). RA signaling is also a known player for regional specification, such that exogenous RA treatment patterns the $\mathrm{CPCs}$ along the anteroposterior axis 
and promotes atrial identity (Xavier-Neto et al. 1999; Hochgreb et al. 2003; Huang et al. 2011; Stefanovic and Zaffran 2017; De Bono et al. 2018). The specific addition of RA at the cardiac mesoderm-CPC stage during hPSC differentiation favors specification toward an atrial-like phenotype $\left(\mathrm{KCNJ}^{+}\right)$at the expense of ventricular fate $\left(\mathrm{MYL}^{+}\right.$) (Zhang et al. 2011; Lee et al. 2017). A study has shown that ventricular hPSCderived CPCs are marked by the expression of CYP26A1, which encodes an enzyme responsible for RA degradation. In contrast, atrial hPSCderived CPCs express RALDH2 (an enzyme required for the synthesis of RA). RALDH2 ${ }^{+} \mathrm{CPCs}$ will preferentially generate atrial CMs (Lee et al. 2017). Consistently, in the mouse model, early Mesp1-expressing CPCs, which contribute preferentially to the LV, express Cyp26a1, whereas atrial Mesp $1^{+}$CPCs that express Mesp1 at later stages preferentially express Raldh2 (Lescroart et al. 2014). Interestingly, ISL1 knockout hPSCs resemble PSC cultures exposed to RA signaling and lead to the preferential specification of atrial CMs. Further investigation showed that ISL1 suppresses the atrial specifier NR2F1. Specification of hPSCs into atrial CMs through RA signaling appears to be mediated by activation of the TALE TF MEIS2, which antagonizes ISL1 expression (Quaranta et al. 2018).

In fish, RA signaling also indirectly counteracts the activity of Isl1 through Ajuba, an LIM domain protein (Witzel et al. 2012). In addition, in vitro studies have demonstrated that the proportion of atrial versus ventricular progenitors can be modulated by different concentrations of Activin A and Bmp4 early during hPSC differentiation (Fig. 4; Lee et al. 2017). It would be very informative to evaluate the levels of BMP4 and Activin A in vivo to see whether this reflects a distinct environmental context for atrial and ventricular progenitors. Furthermore, differentiation protocols established so far do not yet allow us to differentiate between LV versus RV or between atrial cardiac cell types, such as right versus left atrial CMs or pacemaker cells. These might be achieved by understanding the specification of the FHF and anterior and pSHF as they contribute to different regions of the heart.
The establishment of spheroids from HCN4GFP/Tbx1-Cre; Rosa-tdTomato mPSCs has allowed the study of FHF versus SHF specification, despite the fact that $T b x 1$ is only expressed in a subpopulation of the SHF. Transcriptomic analysis demonstrated that Bmp signaling is enriched in $\mathrm{HCN}^{+}$FHF progenitors, whereas Wnt signaling appears to be specific to Tbx1derived SHF cells. Modulating levels of Bmp4 or Wnt3A demonstrated that Bmp4 can promote FHF or $\mathrm{Tb} \times 1^{+} \mathrm{SHF}$ specification depending on its concentration, whereas $\mathrm{Wnt} 3 \mathrm{a}$ specifically promotes the appearance of the Tbx1-derived SHF population. Interestingly, the same study showed that Cxcr4, which initially marks early CPCs, is not expressed later in the FHF and specifically labels the $T b x 1^{+} \mathrm{SHF}$ population (Andersen et al. 2018).

Finally, scRNA-seq has enabled prediction of lineage specifiers for specific cardiac regions. For example, Hopx, Chd3, and Ncor1 and Shox2, Sox4, and Hoxb4 were among the major genes predicted to play a role in the specification of the atrial or sinus venosus lineages, respectively. Similarly, Nr1d 1 could be a cell fate determinant for the RV, whereas Hand2, Msx1 may specify the OFT (de Soysa et al. 2018). Indeed, scRNAseq of Hand2-null cells shows dysregulation of the RV and OFT gene program with abnormal activation of posterior genes, but these data suggest a failure of RV cells to migrate to their final location rather than a defect in their specification (de Soysa et al. 2018). Similarly, ectopic expression of Hoxb1 in aSHF CPCs causes deregulation of the aSHF gene program, suggesting that homeodomain genes play a key role in the anteroposterior patterning and cell identity of CPCs (Stefanovic et al. 2019). Relatedly, in tunicates, knockout of the SHP-specific gene Dach in multipotent CPCs led to ectopic expression of the FHP marker Mmp21, suggesting a change in cell fate identity (Wang et al. 2019).

\section{Cardiomyocyte Versus Skeletal Muscle Fate}

As discussed above, the CPF is able to differentiate into both cardiac tissue and skeletal muscles of the head and neck. Several studies in mice, chick, and fish have shown that there is a 
conserved regulatory network (including $T b \times 1$, Pitx2, Nkx2-5, and Isl1) that governs cardiac and skeletal muscle progenitor specification (Tirosh-Finkel et al. 2006; Nathan et al. 2008; Sambasivan et al. 2009; Nevis et al. 2013; Paffett-Lugassy et al. 2017; Guner-Ataman et al. 2018). Interestingly, fundamental insights on how the CPF is able to differentiate into cardiac or skeletal muscle lineages arise from studies in C. robusta. It is now clear that in tunicates, there is an antagonism between Nk4 (homolog of Nkx2-5) and $T b x 1 / 10$ to regulate cardiac versus skeletal muscle specification. Thus, in committed cardiac progenitors, NK4 inhibits Tbx1/10dependent activation of Ebf, whereas in atrial siphon muscle (ASM) progenitors, NK4 is repressed, thereby allowing $\mathrm{Tbx} 1 / 10$ to activate the skeletal muscle program (Wang et al. 2013). Ebf is then required for differentiation of ASMs by promoting the pharyngeal myogenic program (Razy-Krajka et al. 2014).

Fgf/MAPK signaling also plays a critical role in Ciona in skeletal versus cardiac specification. Activated in multipotent progenitors, Fgf signaling is then maintained only in the lateralmost daughter cells during cell division within the CPF lineage. Fgf signaling is thereafter restricted to ASM progenitors, thus promoting skeletal muscle identity (Razy-Krajka et al. 2018). Even if a role for Fgf signaling in cardiac versus skeletal muscle specification has not yet been shown in vertebrates, it is required for development of the CPF (Abu-Issa et al. 2002; Vitelli et al. 2002; Brown et al. 2004; Hu et al. 2004; Aggarwal et al. 2006; Ilagan et al. 2006; Park et al. 2006, 2008; Kelly and Papaioannou 2007; de Pater et al. 2009; Watanabe et al. 2010, 2012; Lazic and Scott 2011).

scRNA-seq in Ciona has further enabled precise investigation of temporal CPC specification. It led to the characterization of 10 discrete regulatory states along specification pseudotime, with identification of "primed" and "de novo" markers that are, respectively, expressed either throughout these states or only in more committed progenitors. About 50\% of cardiac or skeletal muscle genes are "primed" and therefore already expressed in multipotent progenitors. Cross comparison with other published
scRNA-seq of developing mouse hearts showed high conservation of the transcriptional network governing cardiac versus skeletal muscle specification (Wang et al. 2019).

Tbx1 mutant embryos show defects in both craniofacial skeletal muscles and heart (Lindsay et al. 2001; Kelly et al. 2004; Lescroart et al. 2015). Through RNA sequencing of wild-type versus tbx1 mutant zebrafish embryos, gdf3-ALK4, a TGF $\mu$ superfamily ligand has been identified as a downstream effector of tbx1 involved in CPC specification (Guner-Ataman et al. 2018). In fish, tbx1 is also required to specify the $\mathrm{nkx} 2.5^{+}$ CPF. Moreover, recent studies have also shown a role for Wnt signaling in the balance between cardiac and skeletal muscle lineages, as Wnt activation during or prior to gastrulation inhibits pharyngeal muscle specification at the expense of cardiac lineages (Mandal et al. 2017). Such a role for Wnt has not been found in tunicates (Kaplan et al. 2019). Other factors have been implicated in pharyngeal muscle specification. NR2F or COUP-TF proteins, downstream targets of RA signaling, have been shown, in fish, to promote posterior pharyngeal muscle specification (muscles analogous to the vertebrate neck muscles) while restricting ventricular CM progenitors (Dohn et al. 2019).

BMP signaling, when applied to differentiating mPSCs, leads to the down-regulation of skeletal muscle markers while promoting cardiac genes. RNA-seq showed that Podxl and Cdh4 are surface markers that could be used to distinguish between committed skeletal and cardiac progenitors, respectively (Chan et al. 2016). After mesoderm induction, dual inhibition of Wnt and Nodal promotes CPC specification, and cells thus express $T b x 1, I s l 1$, and Nkx2-5. With specific culture conditions, it is then possible to specify the CPF into skeletal muscle fibers with a cocktail of signaling molecules including a Bmp inhibitor, Hgf, Fgf2, and Igf1 or into beating CMs when supplemented with ascorbic acid, Vegf, Fgf2, and Fgf10 (Nandkishore et al. 2018).

\section{CONCLUDING REMARKS}

The specification of CPCs is a complex developmental process that occurs concomitantly 
Cardiopharyngeal Progenitor Specification

with their migration. Mesp1, a key transcription master regulator of CPC specification, has also a critical role in CPC migration by controlling the epithelial-to-mesenchymal transition, cell polarity, and migration speed (Bondue et al. 2008; Lindsley et al. 2008; Chiapparo et al. 2016). Therefore, it would be important to integrate both CPC migratory trajectories and lineage behavior to investigate the influence of each process on the other. In addition, it is well established that left-right asymmetry is critical for proper heart development (Desgrange et al. 2018), but it is not clear how this affects CPC specification.

With the emergence of single-cell approaches, the model of CPC specification has changed, and it is now clear that CPCs represent a very heterogeneous and dynamic population of progenitors, reflecting distinct physical positions in space and time but also some stochastic factors. In addition, recent research has shown that early CPCs are "primed" toward a particular lineage very early during embryonic development. The determinants of this early "primed" transcriptional heterogeneity are not yet understood. Comprehending the regulation of CPC specification will help to decipher the developmental mechanisms leading to congenital heart disease, which affect $\sim 1 \%$ of newborns worldwide (Srivastava 2006).

In addition, investigating the embryonic regulation of CPC specification has already significantly improved differentiation protocols of PSCs toward a specific cell type. This is particularly relevant in the context of cell therapy after cardiac injury. The identification of multipotent CPCs has brought significant hope to the field of heart repair and further research into the early steps of CPC specification will undoubtedly lead to the design of strategies to specify multipotent CPCs into a specific mature cardiac cell type that could then be used for cell therapy. As a recent example, hPSC-derived CMs have recently been grafted into infarcted pig hearts and showed significant engraftment, although accompanied by ventricular tachyarrhythmia (Romagnuolo et al. 2019). Further improvements are thus required to successfully repair infarcted hearts in patients.

\section{ACKNOWLEDGMENTS}

We regret that many relevant references were not cited because of space constraints. We thank L. Christiaen, R. Kelly, and the members of the Zaffran laboratory for helpful comments. B.S. is supported by the FNRS. F.L. is an INSERM fellow.

\section{REFERENCES}

Abu-Issa R, Smyth G, Smoak I, Yamamura K, Meyers EN. 2002. Fgf8 is required for pharyngeal arch and cardiovascular development in the mouse. Development 129: 46134625.

Aggarwal VS, Liao J, Bondarev A, Schimmang T, Lewandoski M, Locker J, Shanske A, Campione M, Morrow BE. 2006. Dissection of Tbx1 and Fgf interactions in mouse models of 22q11DS suggests functional redundancy. Hum Mol Genet 15: 3219-3228. doi:10.1093/hmg/ dd1399

Andersen P, Tampakakis E, Jimenez DV, Kannan S, Miyamoto M, Shin HK, Saberi A, Murphy S, Sulistio E, Chelko SP, et al. 2018. Precardiac organoids form two heart fields via Bmp/Wnt signaling. Nat Commun 9: 3140. doi:10 .1038/s41467-018-05604-8

Asahina K, Tsai SY, Li P, Ishii M, Maxson RE Jr, Sucov HM, Tsukamoto H. 2009. Mesenchymal origin of hepatic stellate cells, submesothelial cells, and perivascular mesenchymal cells during mouse liver development. Hepatology 49: 998-1011. doi:10.1002/hep.22721

Auda-Boucher G, Bernard B, Fontaine-Pérus J, Rouaud T, Mericksay M, Gardahaut MF. 2000. Staging of the commitment of murine cardiac cell progenitors. Dev Biol 225: 214-225. doi:10.1006/dbio.2000.9817

Azpiazu N, Frasch M. 1993. tinman and bagpipe: two homeo box genes that determine cell fates in the dorsal mesoderm of Drosophila. Genes Dev 7: 1325-1340. doi:10 $.1101 /$ gad.7.7b.1325

Bao X, Lian X, Hacker TA, Schmuck EG, Qian T, Bhute VJ, Han T, Shi M, Drowley L, Plowright A, et al. 2016. Longterm self-renewing human epicardial cells generated from pluripotent stem cells under defined xeno-free conditions. Nat Biomed Eng 1: 0003.

Bardot E, Calderon D, Santoriello F, Han S, Cheung K, Jadhav B, Burtscher I, Artap S, Jain R, Epstein J, et al. 2017. Foxa2 identifies a cardiac progenitor population with ventricular differentiation potential. Nat Commun 8: 14428 doi:10.1038/ncomms14428

Barnes RM, Firulli BA, Conway SJ, Vincentz JW, Firulli AB. 2010. Analysis of the Hand 1 cell lineage reveals novel contributions to cardiovascular, neural crest, extra-embryonic, and lateral mesoderm derivatives. Dev Dyn 239: 3086-3097. doi:10.1002/dvdy.22428

Beh J, Shi W, Levine M, Davidson B, Christiaen L. 2007. FoxF is essential for FGF-induced migration of heart progenitor cells in the ascidian Ciona intestinalis. Development 134: 3297-3305. doi:10.1242/dev.010140

Bertrand N, Roux M, Ryckebüsch L, Niederreither K, Dollé P, Moon A, Capecchi M, Zaffran S. 2011. Hox genes 
define distinct progenitor sub-domains within the second heart field. Dev Biol 353: 266-274. doi:10.1016/j.ydbio .2011.02.029

Bodmer R. 1993. The gene tinman is required for specification of the heart and visceral muscles in Drosophila. Development 118: 719-729.

Bondue A, Blanpain C. 2010. Mesp1: a key regulator of cardiovascular lineage commitment. Circ Res 107: 14141427. doi:10.1161/CIRCRESAHA.110.227058

Bondue A, Lapouge G, Paulissen C, Semeraro C, Iacovino M, Kyba M, Blanpain C. 2008. Mesp1 acts as a master regulator of multipotent cardiovascular progenitor specification. Cell Stem Cell 3: 69-84. doi:10.1016/j.stem.2008.06 .009

Bondue A, Tännler S, Chiapparo G, Chabab S, Ramialison M, Paulissen C, Beck B, Harvey R, Blanpain C. 2011. Defining the earliest step of cardiovascular progenitor specification during embryonic stem cell differentiation. J Cell Biol 192: 751-765. doi:10.1083/jcb.201007063

Brown CB, Wenning JM, Lu MM, Epstein DJ, Meyers EN, Epstein JA. 2004. Cre-mediated excision of Fgf8 in the Tbx1 expression domain reveals a critical role for Fgf8 in cardiovascular development in the mouse. Dev Biol 267: 190-202. doi:10.1016/j.ydbio.2003.10.024

Buckingham M, Meilhac S, Zaffran S. 2005. Building the mammalian heart from two sources of myocardial cells. Nat Rev Genet 6: 826-835. doi:10.1038/nrg1710

Chabab S, Lescroart F, Rulands S, Mathiah N, Simons BD, Blanpain C. 2016. Uncovering the number and clonal dynamics of Mespl progenitors during heart morphogenesis. Cell Rep 14: 1-10. doi:10.1016/j.celrep.2015.12 .013

Chan SS, Shi X, Toyama A, Arpke RW, Dandapat A, Iacovino M, Kang J, Le G, Hagen HR, Garry DJ, et al. 2013. Mesp1 patterns mesoderm into cardiac, hematopoietic, or skeletal myogenic progenitors in a context-dependent manner. Cell Stem Cell 12: 587-601. doi:10.1016/j.stem 2013.03.004

Chan SS, Chan HHW, Kyba M. 2016. Heterogeneity of

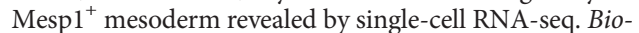
chem Biphys Res Commun 474: 469-475. doi:10.1016/j .bbrc.2016.04.139

Chang CP, Bruneau BG. 2012. Epigenetics and cardiovascular development. Annu Rev Physiol 74: 41-68. doi:10 .1146/annurev-physiol-020911-153242

Chiapparo G, Lin X, Lescroart F, Chabab S, Paulissen C, Pitisci L, Bondue A, Blanpain C. 2016. Mesp1 controls the speed, polarity, and directionality of cardiovascular progenitor migration. J Cell Biol 213: 463-477. doi:10 .1083/jcb.201505082

Choquet C, Marcadet L, Beyer S, Kelly RG, Miquerol L. 2016. Segregation of central ventricular conduction system lineages in early $\mathrm{SMA}^{+}$cardiomyocytes occurs prior to heart tube formation. J Cardiovasc Dev Dis 3: E2.

Christiaen L, Davidson B, Kawashima T, Powell W, Nolla H, Vranizan K, Levine M. 2008. The transcription/migration interface in heart precursors of Ciona intestinalis. Science 320: 1349-1352. doi:10.1126/science.1158170

Christiaen L, Stolfi A, Davidson B, Levine M. 2009. Spatiotemporal intersection of Lhx3 and Tbx6 defines the cardiac field through synergistic activation of Mesp. Dev Biol 328: 552-560. doi:10.1016/j.ydbio.2009.01.033
Conlon FL, Lyons KM, Takaesu N, Barth KS, Kispert A, Herrmann B, Robertson EJ. 1994. A primary requirement for nodal in the formation and maintenance of the primitive streak in the mouse. Development 120: 1919-1928.

Costello I, Pimeisl IM, Dräger S, Bikoff EK, Robertson EJ, Arnold SJ. 2011. The T-box transcription factor Eomesodermin acts upstream of Mesp1 to specify cardiac mesoderm during mouse gastrulation. Nat Cell Biol 13: 10841091. doi:10.1038/ncb2304

David R, Brenner C, Stieber J, Schwarz F, Brunner S, Vollmer M, Mentele E, Müller-Höcker J, Kitajima S, Lickert H, et al. 2008. MesP1 drives vertebrate cardiovascular differentiation through Dkk-1-mediated blockade of Wnt-signalling. Nat Cell Biol 10: 338-345. doi:10.1038/ncb1696

David R, Jarsch VB, Schwarz F, Nathan P, Gegg M, Lickert H, Franz WM. 2011. Induction of MesP1 by Brachyury(T) generates the common multipotent cardiovascular stem cell. Cardiovasc Res 92: 115-122. doi:10.1093/cvr/cvr158

Davidson B, Shi W, Levine M. 2005. Uncoupling heart cell specification and migration in the simple chordate Ciona intestinalis. Development 132: 4811-4818. doi:10.1242/ dev.02051

Davidson B, Shi W, Beh J, Christiaen L, Levine M. 2006. FGF signaling delineates the cardiac progenitor field in the simple chordate, Ciona intestinalis. Genes Dev 20: 2728-2738. doi:10.1101/gad.1467706

De Bono C, Thellier C, Bertrand N, Sturny R, Jullian E, Cortes C, Stefanovic S, Zaffran S, Théveniau-Ruissy M, Kelly RG. 2018. T-box genes and retinoic acid signaling regulate the segregation of arterial and venous pole progenitor cells in the murine second heart field. Hum Mol Genet 27: 3747-3760.

Den Hartogh SC, Schreurs C, Monshouwer-Kloots JJ, Davis RP, Elliott DA, Mummery CL, Passier R. 2015. Dual reporter MESP $1^{m C h e r r y / w}{ }_{-N K X 2-5^{e G F P / w}}$ hESCs enable studying early human cardiac differentiation. Stem Cells 33: 56-67. doi:10.1002/stem.1842

de Pater E, Clijsters L, Marques SR, Lin YF, Garavito-Aguilar ZV, Yelon D, Bakkers J. 2009. Distinct phases of cardiomyocyte differentiation regulate growth of the zebrafish heart. Development 136: 1633-1641. doi:10.1242/dev .030924

de Soysa TY, Ranade SS, Okawa S, Ravichandran S, Huang Y, Salunga HT, Schricker A, Del Sol A, Gifford CA, Srivastava D. 2018. Single-cell transcriptome analysis during cardiogenesis reveals basis for organ level developmental anomalies. bioRxiv 365734. doi:10.1101/365734.

Desgrange A, Le Garrec JF, Meilhac SM. 2018. Left-right asymmetry in heart development and disease: forming the right loop. Development 145: dev162776. doi:10 $.1242 /$ dev. 162776

Deshwar AR, Onderisin JC, Aleksandrova A, Yuan X, Burrows JTA, Scott IC. 2016. Mespaa can potently induce cardiac fates in zebrafish. Dev Biol 418: 17-27. doi:10 .1016/j.ydbio.2016.08.022

Devine WP, Wythe JD, George M, Koshiba-Takeuchi K, Bruneau BG. 2014. Early patterning and specification of cardiac progenitors in gastrulating mesoderm. eLife 3: 03848. doi:10.7554/eLife.03848

Diogo R, Kelly RG, Christiaen L, Levine M, Ziermann JM, Molnar JL, Noden DM, Tzahor E. 2015. A new heart for a 
new head in vertebrate cardiopharyngeal evolution. $\mathrm{Na}$ ture 520: 466-473. doi:10.1038/nature14435

Dohn TE, Ravisankar P, Tirera FT, Martin KE, Gafranek JT, Duong TB, VanDyke TL, Touvron M, Barske LA, Crump JG, et al. 2019. Nr2f-dependent allocation of ventricular cardiomyocyte and pharyngeal muscle progenitors. PLoS Genet 15: e1007962. doi:10.1371/journal.pgen.1007962

Drukker M, Tang C, Ardehali R, Rinkevich Y, Seita J, Lee AS, Mosley AR, Weissman IL, Soen Y. 2012. Isolation of primitive endoderm, mesoderm, vascular endothelial and trophoblast progenitors from human pluripotent stem cells. Nat Biotechnol 30: 531-542. doi:10.1038/nbt .2239

Ema M, Takahashi S, Rossant J. 2006. Deletion of the selection cassette, but not cis-acting elements, in targeted Flk1lac $Z$ allele reveals $F l k 1$ expression in multipotent mesodermal progenitors. Blood 107: 111-117. doi:10.1182/ blood-2005-05-1970

Frasch M. 1995. Induction of visceral and cardiac mesoderm by ectodermal Dpp in the early Drosophila embryo. $\mathrm{Na}$ ture 374: 464-467. doi:10.1038/374464a0

Fujii M, Sakaguchi A, Kamata R, Nagao M, Kikuchi Y, Evans SM, Yoshizumi M, Shimono A, Saga Y, Kokubo H. 2017. Sfrp5 identifies murine cardiac progenitors for all myocardial structures except for the right ventricle. Nat Commun 8: 14664. doi:10.1038/ncomms14664

Gadue P, Huber TL, Paddison PJ, Keller GM. 2006. Wnt and TGF- $\beta$ signaling are required for the induction of an in vitro model of primitive streak formation using embryonic stem cells. Proc Natl Acad Sci 103: 16806-16811. doi:10.1073/pnas.0603916103

Guadix JA, Orlova VV, Giacomelli E, Bellin M, Ribeiro MC, Mummery CL, Pérez-Pomares JM, Passier R. 2017. Human pluripotent stem cell differentiation into functional epicardial progenitor cells. Stem Cell Rep 9: 1754-1764. doi:10.1016/j.stemcr.2017.10.023

Guner-Ataman B, González-Rosa JM, Shah HN, Butty VL, Jeffrey S, Abrial M, Boyer LA, Burns CG, Burns CE. 2018. Failed progenitor specification underlies the cardiopharyngeal phenotypes in a Zebrafish model of 22q11.2 deletion syndrome. Cell Rep 24: 1342-1354.e5. doi:10.1016/j .celrep.2018.06.117

Guo X, Xu Y, Wang Z, Wu Y, Chen J, Wang G, Lu C, Jia W, Xi J, Zhu S, et al. 2018. A Linc1405/Eomes complex promotes cardiac mesoderm specification and cardiogenesis. Cell Stem Cell 22: 893-908.e6. doi:10.1016/j.stem.2018.04 .013

Haegel H, Larue L, Ohsugi M, Fedorov L, Herrenknecht K, Kemler R. 1995. Lack of $\beta$-catenin affects mouse development at gastrulation. Development 121: 3529-3537.

Harel I, Nathan E, Tirosh-Finkel L, Zigdon H, GuimarãesCamboa N, Evans SM, Tzahor E. 2009. Distinct origins and genetic programs of head muscle satellite cells. Dev Cell 16: 822-832. doi:10.1016/j.devcel.2009.05.007

Harvey RP. 2002. Patterning the vertebrate heart. Nat Rev Genet 3: 544-556. doi:10.1038/nrg843

He A, Kong SW, Ma Q, Pu WT. 2011. Co-occupancy by multiple cardiac transcription factors identifies transcriptional enhancers active in heart. Proc Natl Acad Sci 108: 5632-5637. doi:10.1073/pnas.1016959108

Hirata H, Kawamata S, Murakami Y, Inoue K, Nagahashi A Tosaka M, Yoshimura N, Miyamoto Y, Iwasaki H, Asa- hara T, et al. 2007. Coexpression of platelet-derived growth factor receptor alpha and fetal liver kinase 1 enhances cardiogenic potential in embryonic stem cell differentiation in vitro. J Biosci Bioeng 103: 412-419. doi:10 $.1263 / \mathrm{jbb} .103 .412$

Hochgreb T, Linhares VL, Menezes DC, Sampaio AC, Yan CY, Cardoso WV, Rosenthal N, Xavier-Neto J. 2003. A caudorostral wave of RALDH2 conveys anteroposterior information to the cardiac field. Development 130: 53635374. doi:10.1242/dev.00750

Hou J, Long $\mathrm{H}$, Zhou C, Zheng S, Wu H, Guo T, Wu Q, Zhong T, Wang T. 2017. Long noncoding RNA Braveheart promotes cardiogenic differentiation of mesenchymal stem cells in vitro. Stem Cell Res Ther 8: 4. doi:10 .1186/s13287-016-0454-5

Hu T, Yamagishi H, Maeda J, McAnally J, Yamagishi C, Srivastava D. 2004. Tbx1 regulates fibroblast growth factors in the anterior heart field through a reinforcing autoregulatory loop involving forkhead transcription factors. Development 131: 5491-5502. doi:10.1242/dev .01399

Huang S, Ma J, Liu X, Zhang Y, Luo L. 2011. Retinoic acid signaling sequentially controls visceral and heart laterality in zebrafish. J Biol Chem 286: 28533-28543. doi:10.1074/ jbc.M111.244327

Ieda M, Fu JD, Delgado-Olguin P, Vedantham V, Hayashi Y, Bruneau BG, Srivastava D. 2010. Direct reprogramming of fibroblasts into functional cardiomyocytes by defined factors. Cell 142: 375-386. doi:10.1016/j.cell.2010.07.002

Ilagan R, Abu-Issa R, Brown D, Yang YP, Jiao K, Schwartz RJ, Klingensmith J, Meyers EN. 2006. Fgf8 is required for anterior heart field development. Development 133: 2435-2445. doi:10.1242/dev.02408

Ionta V, Liang W, Kim EH, Rafie R, Giacomello A, Marbán E, Cho HC. 2015. SHOX2 overexpression favors differentiation of embryonic stem cells into cardiac pacemaker cells, improving biological pacing ability. Stem Cell Rep 4: 129-142. doi:10.1016/j.stemcr.2014.11.004

Iyer D, Gambardella L, Bernard WG, Serrano F, Mascetti VL, Pedersen RA, Talasila A, Sinha S. 2015. Robust derivation of epicardium and its differentiated smooth muscle cell progeny from human pluripotent stem cells. Development 142: 1528-1541. doi:10.1242/dev.119271

Jung JJ, Husse B, Rimmbach C, Krebs S, Stieber J, Steinhoff G, Dendorfer A, Franz WM, David R. 2014. Programming and isolation of highly pure physiologically and pharmacologically functional sinus-nodal bodies from pluripotent stem cells. Stem Cell Rep 2: 592-605. doi:10 $.1016 /$ j.stemcr.2014.03.006

Kaplan NA, Wang W, Christiaen L. 2019. Initial characterization of Wnt-Tcf functions during Ciona heart development. Dev Biol 448: 199-209. doi:10.1016/j.ydbio.2018 .12 .018

Kataoka H, Takakura N, Nishikawa S, Tsuchida K, Kodama H, Kunisada T, Risau W, Kita T, Nishikawa SI. 1997. Expressions of PDGF receptor alpha, $c$-Kit and Flk1 genes clustering in mouse chromosome 5 define distinct subsets of nascent mesodermal cells. Dev Growth Differ 39: 729740. doi:10.1046/j.1440-169X.1997.t01-5-00009.x

Kattman SJ, Huber TL, Keller GM. 2006. Multipotent Flk-1 ${ }^{+}$ cardiovascular progenitor cells give rise to the cardiomyo- 
cyte, endothelial, and vascular smooth muscle lineages. Dev Cell 11: 723-732. doi:10.1016/j.devcel.2006.10.002

Kattman SJ, Witty AD, Gagliardi M, Dubois NC, Niapour M, Hotta A, Ellis J, Keller G. 2011. Stage-specific optimization of activin/nodal and BMP signaling promotes cardiac differentiation of mouse and human pluripotent stem cell lines. Cell Stem Cell 8: 228-240. doi:10.1016/j .stem.2010.12.008

Kelly RG, Papaioannou VE. 2007. Visualization of outflow tract development in the absence of Tbx1 using an FgF10 enhancer trap transgene. Dev Dyn 236: 821-828. doi:10 $.1002 /$ dvdy.21063

Kelly RG, Jerome-Majewska LA, Papaioannou VE. 2004. The del22q11.2 candidate gene $T b x 1$ regulates branchiomeric myogenesis. Hum Mol Genet 13: 2829-2840. doi:10 $.1093 / \mathrm{hmg} / \mathrm{ddh} 304$

Kinder SJ, Tsang TE, Quinlan GA, Hadjantonakis AK, Nagy A, Tam PP. 1999. The orderly allocation of mesodermal cells to the extraembryonic structures and the anteroposterior axis during gastrulation of the mouse embryo. $D e-$ velopment 126: 4691-4701.

Kirby ML, Waldo KL. 1995. Neural crest and cardiovascular patterning. Circ Res 77: 211-215. doi:10.1161/01.RES.77 .2 .211

Kirby ML, Gale TF, Stewart DE. 1983. Neural crest cells contribute to normal aorticopulmonary septation. Science 220: 1059-1061. doi:10.1126/science.6844926

Kispert A, Herrmann BG. 1993. The Brachyury gene encodes a novel DNA binding protein. EMBO J 12: 3211 3220. doi:10.1002/j.1460-2075.1993.tb05990.x

Kitajima S, Takagi A, Inoue T, Saga Y. 2000. MesP1 and MesP2 are essential for the development of cardiac mesoderm. Development 127: 3215-3226.

Klattenhoff CA, Scheuermann JC, Surface LE, Bradley RK, Fields PA, Steinhauser ML, Ding H, Butty VL, Torrey L, Haas S, et al. 2013. Braveheart, a long noncoding RNA required for cardiovascular lineage commitment. Cell 152: 570-583. doi:10.1016/j.cell.2013.01.003

Kokkinopoulos I, Ishida H, Saba R, Ruchaya P, Cabrera C, Struebig M, Barnes M, Terry A, Kaneko M, Shintani Y, et al. 2015. Single-cell expression profiling reveals a dynamic state of cardiac precursor cells in the early mouse embryo. PLoS ONE 10: e0140831. doi:10.1371/journal.pone .0140831

Kouskoff V, Lacaud G, Schwantz S, Fehling HJ, Keller G. 2005. Sequential development of hematopoietic and cardiac mesoderm during embryonic stem cell differentiation. Proc Natl Acad Sci 102: 13170-13175. doi:10.1073/ pnas.0501672102

Laflamme MA, Chen KY, Naumova AV, Muskheli V, Fugate JA, Dupras SK, Reinecke H, Xu C, Hassanipour M, Police S, et al. 2007. Cardiomyocytes derived from human embryonic stem cells in pro-survival factors enhance function of infarcted rat hearts. Nat Biotechnol 25: 1015-1024. doi:10.1038/nbt1327

Lawson KA. 1999. Fate mapping the mouse embryo. Int $J$ Dev Biol 43: 773-775.

Lazic S, Scott IC. 2011. Mef2cb regulates late myocardial cell addition from a second heart field-like population of progenitors in zebrafish. Dev Biol 354: 123-133. doi:10.1016/ j.ydbio.2011.03.028
Lee JH, Protze SI, Laksman Z, Backx PH, Keller GM. 2017. Human pluripotent stem cell-derived atrial and ventricular cardiomyocytes develop from distinct mesoderm populations. Cell Stem Cell 21: 179-194.e4. doi:10.1016/ j.stem.2017.07.003

Lescroart F, Meilhac SM. 2012. Cell lineages, growth and repair of the mouse heart. Results Probl Cell Differ 55: 263-289.

Lescroart F, Kelly RG, Le Garrec JF, Nicolas JF, Meilhac SM, Buckingham M. 2010. Clonal analysis reveals common lineage relationships between head muscles and second heart field derivatives in the mouse embryo. Development 137: 3269-3279. doi:10.1242/dev.050674

Lescroart F, Chabab S, Lin X, Rulands S, Paulissen C, Rodolosse A, Auer H, Achouri Y, Dubois C, Bondue A, et al. 2014. Early lineage restriction in temporally distinct populations of Mesp1 progenitors during mammalian heart development. Nat Cell Biol 16: 829-840. doi:10.1038/ ncb3024

Lescroart F, Hamou W, Francou A, Théveniau-Ruissy M, Kelly RG, Buckingham M. 2015. Clonal analysis reveals a common origin between nonsomite-derived neck muscles and heart myocardium. Proc Natl Acad Sci 112: 1446-1451. doi:10.1073/pnas.1424538112

Lescroart F, Wang X, Lin X, Swedlund B, Gargouri S, Sànchez-Danes A, Moignard V, Dubois C, Paulissen C, Kinston S, et al. 2018. Defining the earliest step of cardiovascular lineage segregation by single-cell RNA-seq. Science 359: 1177-1181. doi:10.1126/science.aao4174

Liang X, Wang G, Lin L, Lowe J, Zhang Q, Bu L, Chen Y, Chen J, Sun Y, Evans SM. 2013. HCN4 dynamically marks the first heart field and conduction system precursors. Circ Res 113: 399-407. doi:10.1161/CIRCRESAHA .113 .301588

Lindsay EA, Vitelli F, Su H, Morishima M, Huynh T, Pramparo T, Jurecic V, Ogunrinu G, Sutherland HF, Scambler PJ, et al. 2001. Tbxi haploinsufficieny in the DiGeorge syndrome region causes aortic arch defects in mice. $\mathrm{Na}$ ture 410: 97-101. doi:10.1038/35065105

Lindsley RC, Gill JG, Murphy TL, Langer EM, Cai M, Mashayekhi M, Wang W, Niwa N, Nerbonne JM, Kyba M, et al. 2008. Mesp1 coordinately regulates cardiovascular fate restriction and epithelial-mesenchymal transition in differentiating ESCs. Cell Stem Cell 3: 55-68. doi:10.1016/ j.stem.2008.04.004

Liu Y. 2017. Earlier and broader roles of Mesp1 in cardiovascular development. Cell Mol Life Sci 74: 1969-1983. doi:10.1007/s00018-016-2448-y

Liu Y, Asakura M, Inoue H, Nakamura T, Sano M, Niu Z, Chen M, Schwartz RJ, Schneider MD. 2007. Sox17 is essential for the specification of cardiac mesoderm in embryonic stem cells. Proc Natl Acad Sci 104: 38593864. doi:10.1073/pnas.0609100104

Loh KM, Chen A, Koh PW, Deng TZ, Sinha R, Tsai JM, Barkal AA, Shen KY, Jain R, Morganti RM, et al. 2016. Mapping the pairwise choices leading from pluripotency to human bone, heart, and other mesoderm cell types. Cell 166: 451-467. doi:10.1016/j.cell.2016.06.011

Luna-Zurita L, Stirnimann CU, Glatt S, Kaynak BL, Thomas S, Baudin F, Samee MA, He D, Small EM, Mileikovsky M, et al. 2016. Complex interdependence regulates heterotypic transcription factor distribution and coordinates 
cardiogenesis. Cell 164: 999-1014. doi:10.1016/j.cell.2016 .01 .004

Lyons I, Parsons LM, Hartley L, Li R, Andrews JE, Robb L, Harvey RP. 1995. Myogenic and morphogenetic defects in the heart tubes of murine embryos lacking the homeo box gene Nkx2-5. Genes Dev 9: 1654-1666. doi:10.1101/ gad.9.13.1654

MacGrogan D, Nus M, de la Pompa JL. 2010. Notch signaling in cardiac development and disease. Curr Topics Dev Biol 92: 333-365. doi:10.1016/S0070-2153(10)92011-5

MacGrogan D, Münch J, de la Pompa JL. 2018. Notch and interacting signalling pathways in cardiac development, disease, and regeneration. Nature Rev Cardiol 15: 685704. doi:10.1038/s41569-018-0100-2

Mandal A, Holowiecki A, Song YC, Waxman JS. 2017. Wnt signaling balances specification of the cardiac and pharyngeal muscle fields. Mech Dev 143: 32-41. doi:10.1016/j .mod.2017.01.003

Marvin MJ, Di Rocco G, Gardiner A, Bush SM, Lassar AB. 2001. Inhibition of Wnt activity induces heart formation from posterior mesoderm. Genes Dev 15: 316-327. doi:10 $.1101 /$ gad.855501

McBratney-Owen B, Iseki S, Bamforth SD, Olsen BR, Morriss-Kay GM. 2008. Development and tissue origins of the mammalian cranial base. Dev Biol 322: 121-132. doi:10 $.1016 /$ j.ydbio.2008.07.016

Meilhac SM, Buckingham ME. 2018. The deployment of cell lineages that form the mammalian heart. Nat Rev Cardiol 15: 705-724. doi:10.1038/s41569-018-0086-9

Meilhac SM, Esner M, Kelly RG, Nicolas JF, Buckingham ME. 2004. The clonal origin of myocardial cells in different regions of the embryonic mouse heart. Dev Cell 6: 685-698. doi:10.1016/S1534-5807(04)00133-9

Mikawa T, Fischman DA. 1996. The polyclonal origin of myocyte lineages. Annu Rev Physiol 58: 509-521. doi:10 .1146/annurev.ph.58.030196.002453

Mishina Y, Suzuki A, Ueno N, Behringer RR. 1995. Bmpr encodes a type I bone morphogenetic protein receptor that is essential for gastrulation during mouse embryogenesis. Genes Dev 9: 3027-3037. doi:10.1101/gad.9.24 .3027

Miura S, Davis S, Klingensmith J, Mishina Y. 2006. BMP signaling in the epiblast is required for proper recruitment of the prospective paraxial mesoderm and development of the somites. Development 133: 3767-3775. doi:10 $.1242 /$ dev.02552

Mommersteeg MT, Domínguez JN, Wiese C, Norden J, de Gier-de Vries C, Burch JB, Kispert A, Brown NA, Moorman AF, Christoffels VM. 2010. The sinus venosus progenitors separate and diversify from the first and second heart fields early in development. Cardiovasc Res 87: 92101. doi: $10.1093 / \mathrm{cvr} / \mathrm{cvq} 033$

Moretti A, Caron L, Nakano A, Lam JT, Bernshausen A, Chen Y, Qyang Y, Bu L, Sasaki M, Martin-Puig S, et al. 2006. Multipotent embryonic $I s l^{+}$progenitor cells lead to cardiac, smooth muscle, and endothelial cell diversification. Cell 127: 1151-1165. doi:10.1016/j.cell.2006.10 .029

Motoike T, Markham DW, Rossant J, Sato TN. 2003. Evidence for novel fate of $\mathrm{Flk1}^{+}$progenitor: contribution to muscle lineage. Genesis 35: 153-159. doi:10.1002/gene .10175
Naito AT, Shiojima I, Akazawa H, Hidaka K, Morisaki T, Kikuchi A, Komuro I. 2006. Developmental stage-specific biphasic roles of Wnt/ $\beta$-catenin signaling in cardiomyogenesis and hematopoiesis. Proc Natl Acad Sci 103: 19812-19817. doi:10.1073/pnas.0605768103

Nandkishore N, Vyas B, Javali A, Ghosh S, Sambasivan R. 2018. Divergent early mesoderm specification underlies distinct head and trunk muscle programmes in vertebrates. Development 145: dev160945.

Nathan E, Monovich A, Tirosh-Finkel L, Harrelson Z, Rousso T, Rinon A, Harel I, Evans SM, Tzahor E. 2008. The contribution of Islet1-expressing splanchnic mesoderm cells to distinct branchiomeric muscles reveals significant heterogeneity in head muscle development. Development 135: 647-657. doi:10.1242/dev.007989

Nelson TJ, Faustino RS, Chiriac A, Crespo-Diaz R, Behfar A, Terzic A. 2008. CXCR $4^{+} /$FLK- $1^{+}$biomarkers select a cardiopoietic lineage from embryonic stem cells. Stem Cells 26: 1464-1473. doi:10.1634/stemcells.2007-0808

Nemir M, Croquelois A, Pedrazzini T, Radtke F. 2006. Induction of cardiogenesis in embryonic stem cells via downregulation of Notch1 signaling. Circ Res 98: 14711478. doi:10.1161/01.RES.0000226497.52052.2a

Neri T, Hiriart E, van Vliet PP, Faure E, Norris RA, Farhat B, Jagla B, Lefrancois J, Sugi Y, Moore-Morris T, et al. 2019. Human pre-valvular endocardial cells derived from pluripotent stem cells recapitulate cardiac pathophysiological valvulogenesis. Nat Commun 10: 1929. doi:10.1038/ s41467-019-09459-5

Nevis K, Obregon P, Walsh C, Guner-Ataman B, Burns CG, Burns CE. 2013. Tbx1 is required for second heart field proliferation in zebrafish. Dev Dyn 242: 550-559. doi:10 $.1002 /$ dvdy. 23928

Noseda M, Schneider MD. 2010. Previews. Unleashing cardiopoiesis: a novel role for G-CSF. Cell Stem Cell 6: 188189. doi:10.1016/j.stem.2010.02.005

Ounzain S, Micheletti R, Arnan C, Plaisance I, Cecchi D, Schroen B, Reverter F, Alexanian M, Gonzales C, Ng SY, et al. 2015. CARMEN, a human super enhancer-associated long noncoding RNA controlling cardiac specification, differentiation and homeostasis. J Mol Cell Cardiol 89: 98-112. doi:10.1016/j.yjmcc.2015.09.016

Paffett-Lugassy N, Novikov N, Jeffrey S, Abrial M, GunerAtaman B, Sakthivel S, Burns CE, Burns CG. 2017. Unique developmental trajectories and genetic regulation of ventricular and outflow tract progenitors in the zebrafish second heart field. Development 144: 4616-4624. doi:10.1242/dev.153411

Paige SL, Osugi T, Afanasiev OK, Pabon L, Reinecke H, Murry CE. 2010. Endogenous Wnt $/ \beta$-catenin signaling is required for cardiac differentiation in human embryonic stem cells. PLoS ONE 5: e11134. doi:10.1371/journal .pone.0011134

Paige SL, Thomas S, Stoick-Cooper CL, Wang H, Maves L, Sandstrom R, Pabon L, Reinecke H, Pratt G, Keller G, et al. 2012. A temporal chromatin signature in human embryonic stem cells identifies regulators of cardiac development. Cell 151: 221-232. doi:10.1016/j.cell.2012.08.027

Park EJ, Ogden LA, Talbot A, Evans S, Cai CL, Black BL, Frank DU, Moon AM. 2006. Required, tissue-specific roles for Fgf8 in outflow tract formation and remodeling. Development 133: 2419-2433. doi:10.1242/dev.02367 
Park EJ, Watanabe Y, Smyth G, Miyagawa-Tomita S, Meyers E, Klingensmith J, Camenisch T, Buckingham M, Moon AM. 2008. An FGF autocrine loop initiated in second heart field mesoderm regulates morphogenesis at the arterial pole of the heart. Development 135: 3599-3610. doi:10.1242/dev.025437

Phillips MD, Mukhopadhyay M, Poscablo C, Westphal H. 2011. Dkk1 and Dkk2 regulate epicardial specification during mouse heart development. Int J Cardiol 150: 186-192. doi:10.1016/j.ijcard.2010.04.007

Protze SI, Liu J, Nussinovitch U, Ohana L, Backx PH, Gepstein L, Keller GM. 2017. Sinoatrial node cardiomyocytes derived from human pluripotent cells function as a biological pacemaker. Nat Biotechnol 35: 56-68. doi:10.1038/ nbt. 3745

Quaranta R, Fell J, Rühle F, Rao J, Piccini I, Araúzo-Bravo MJ, Verkerk AO, Stoll M, Greber B. 2018. Revised roles of ISL1 in a hES cell-based model of human heart chamber specification. eLife 7: e31706 doi:10.7554/eLife.31706

Qyang Y, Martin-Puig S, Chiravuri M, Chen S, Xu H, Bu L, Jiang X, Lin L, Granger A, Moretti A, et al. 2007. The renewal and differentiation of $\mathrm{Isl}^{+}$cardiovascular progenitors are controlled by a Wnt/ $\beta$-catenin pathway. Cell Stem Cell 1: 165-179. doi:10.1016/j.stem.2007.05.018

Racioppi C, Wiechecki KA, Christiaen L. 2019. Combinatorial chromatin dynamics foster accurate cardiopharyngeal fate choices. bioRxiv 546945. doi:10.1101/546945.

Razy-Krajka F, Lam K, Wang W, Stolfi A, Joly M, Bonneau R, Christiaen L. 2014. Collier/OLF/EBF-dependent transcriptional dynamics control pharyngeal muscle specification from primed cardiopharyngeal progenitors. Dev Cell 29: 263-276. doi:10.1016/j.devcel.2014.04.001

Razy-Krajka F, Gravez B, Kaplan N, Racioppi C, Wang W, Christiaen L. 2018. An FGF-driven feed-forward circuit patterns the cardiopharyngeal mesoderm in space and time. eLife 7. doi:10.7554/eLife.29656

Romagnuolo R, Masoudpour H, Porta-Sánchez A, Qiang B, Barry J, Laskary A, Qi X, MasséS, Magtibay K, Kawajiri H, et al. 2019. Human embryonic stem cell-derived cardiomyocytes regenerate the infarcted pig heart but induce ventricular tachyarrhythmias. Stem Cell Rep 12: 967981. doi:10.1016/j.stemcr.2019.04.005

Saba R, Kitajima K, Rainbow L, Engert S, Uemura M, Ishida H, Kokkinopoulos I, Shintani Y, Miyagawa S, Kanai Y, et al. 2019. Sox17 expression in endocardium precursor cells regulates heart development in mice. bioRxiv 548289. doi:10.1101/548289

Sadahiro T, Isomi M, Muraoka N, Kojima H, Haginiwa S, Kurotsu S, Tamura F, Tani H, Tohyama S, Fujita J, et al. 2018. Tbx6 induces nascent mesoderm from pluripotent stem cells and temporally controls cardiac versus somite lineage diversification. Cell Stem Cell 23: 382-395.e5. doi:10.1016/j.stem.2018.07.001

Saga Y, Hata N, Kobayashi S, Magnuson T, Seldin MF, Taketo MM. 1996. MesP1: a novel basic helix-loop-helix protein expressed in the nascent mesodermal cells during mouse gastrulation. Development 122: 2769-2778.

Saga Y, Miyagawa-Tomita S, Takagi A, Kitajima S, Miyazaki J, Inoue T. 1999. MesP1 is expressed in the heart precursor cells and required for the formation of a single heart tube. Development 126: 3437-3447.
Saga Y, Kitajima S, Miyagawa-Tomita S. 2000. Mesp1 expression is the earliest sign of cardiovascular development. Trends Cardiovasc Med 10: 345-352. doi:10.1016/ S1050-1738(01)00069-X

Saint-Jean L, Barkas N, Harmelink C, Tompkins KL, Oakey RJ, Baldwin HS. 2019. Myocardial differentiation is dependent upon endocardial signaling during early cardiogenesis in vitro. Development 146: dev172619. doi:10 $.1242 /$ dev. 172619

Sambasivan R, Gayraud-Morel B, Dumas G, Cimper C, Paisant S, Kelly RG, Tajbakhsh S. 2009. Distinct regulatory cascades govern extraocular and pharyngeal arch muscle progenitor cell fates. Dev Cell 16: 810-821. doi:10.1016/j devcel.2009.05.008

Satou Y, Imai KS, Satoh N. 2004. The ascidian Mesp gene specifies heart precursor cells. Development 131: 2533 2541. doi:10.1242/dev.01145

Schneider VA, Mercola M. 2001. Wnt antagonism initiates cardiogenesis in Xenopus laevis. Genes Dev 15: 304-315. doi:10.1101/gad.855601

Schott JJ, Benson DW, Basson CT, Pease W, Silberbach GM, Moak JP, Maron BJ, Seidman CE, Seidman JG. 1998. Congenital heart disease caused by mutations in the transcription factor NKX2-5. Science 281: 108-111. doi:10 $.1126 /$ science.281.5373.108

Schroeder T, Fraser ST, Ogawa M, Nishikawa S, Oka C, Bornkamm GW, Nishikawa S, Honjo T, Just U. 2003. Recombination signal sequence-binding protein JK alters mesodermal cell fate decisions by suppressing cardiomyogenesis. Proc Natl Acad Sci 100: 4018-4023. doi:10 $.1073 /$ pnas. 0438008100

Shim WJ, Sinniah E, Xu J, Vitrinel B, Alexanian M, Andreoletti G, Shen S, Balderson B, Peng G, Jing N, et al. 2019. Comparative analysis of diverse cell states establishes an epigenetic basis for inferring regulatory genes governing cell identity. bioRxiv 635516. doi:10.1101/635516.

Showell C, Binder O, Conlon FL. 2004. T-box genes in early embryogenesis. Dev Dyn 229: 201-218.

Skelton RJ, Brady B, Khoja S, Sahoo D, Engel J, Arasaratnam D, Saleh KK, Abilez OJ, Zhao P, Stanley EG, et al. 2016. CD13 and ROR2 permit isolation of highly enriched cardiac mesoderm from differentiating human embryonic stem cells. Stem Cell Rep 6: 95-108. doi:10.1016/j.stemcr .2015 .11 .006

Spater D, Abramczuk MK, Buac K, Zangi L, Stachel MW, Clarke J, Sahara M, Ludwig A, Chien KR. 2013. A HCN4 ${ }^{+}$ cardiomyogenic progenitor derived from the first heart field and human pluripotent stem cells. Nat Cell Biol 15: 1098-1106.

Srivastava D. 2006. Genetic regulation of cardiogenesis and congenital heart disease. Annu Rev Pathol 1: 199-213. doi:10.1146/annurev.pathol.1.110304.100039

Stalsberg H, DeHaan RL. 1969. The precardiac areas and formation of the tubular heart in the chick embryo. Dev Biol 19: 128-159. doi:10.1016/0012-1606(69)90052-9

Stefanovic S, Zaffran S. 2017. Mechanisms of retinoic acid signaling during cardiogenesis. Mech Dev 143: 9-19. doi:10.1016/j.mod.2016.12.002

Stefanovic S, Laforest B, Desvignes, JP, Lescroart F, Argiro L, Maurel-Zaffran C, Salgado D, Bono C, Pazur K, Théveniau-Ruissy M, et al. 2019. Hox-dependent coordination 
of cardiac cell patterning and differentiation. SSRN Electronic J doi: 10.2139/ssrn.3329886

Stolfi A, Gainous TB, Young JJ, Mori A, Levine M, Christiaen L. 2010. Early chordate origins of the vertebrate second heart field. Science 329: 565-568. doi:10.1126/science .1190181

Takeuchi JK, Bruneau BG. 2009. Directed transdifferentiation of mouse mesoderm to heart tissue by defined factors. Nature 459: 708-711. doi:10.1038/nature08039

Tam PP, Behringer RR. 1997. Mouse gastrulation: the formation of a mammalian body plan. Mech Dev 68: 3-25. doi:10.1016/S0925-4773(97)00123-8

Tanaka M, Chen Z, Bartunkova S, Yamasaki N, Izumo S. 1999. The cardiac homeobox gene Csx/Nkx2.5 lies genetically upstream of multiple genes essential for heart development. Development 126: 1269-1280.

Tirosh-Finkel L, Elhanany H, Rinon A, Tzahor E. 2006. Mesoderm progenitor cells of common origin contribute to the head musculature and the cardiac outflow tract. Development 133: 1943-1953. doi:10.1242/dev.02365

Tzahor E, Lassar AB. 2001. Wnt signals from the neural tube block ectopic cardiogenesis. Genes Dev 15: 255-260. doi:10.1101/gad.871501

Tzahor E, Kempf H, Mootoosamy RC, Poon AC, Abzhanov A, Tabin CJ, Dietrich S, Lassar AB. 2003. Antagonists of Wnt and BMP signaling promote the formation of vertebrate head muscle. Genes Dev 17: 3087-3099. doi:10 $.1101 /$ gad.1154103

Ueno S, Weidinger G, Osugi T, Kohn AD, Golob JL, Pabon L, Reinecke H, Moon RT, Murry CE. 2007. Biphasic role for $\mathrm{Wnt} / \beta$-catenin signaling in cardiac specification in zebrafish and embryonic stem cells. Proc Natl Acad Sci 104: 9685-9690. doi:10.1073/pnas.0702859104

van den Ameele J, Tiberi L, Bondue A, Paulissen C, Herpoel A, Iacovino M, Kyba M, Blanpain C, Vanderhaeghen P. 2012. Eomesodermin induces Mesp1 expression and cardiac differentiation from embryonic stem cells in the absence of Activin. EMBO Rep 13: 355-362. doi:10.1038/ embor.2012.23

Van Handel B, Montel-Hagen A, Sasidharan R, Nakano H, Ferrari R, Boogerd CJ, Schredelseker J, Wang Y, Hunter S, Org T, et al. 2012. Scl represses cardiomyogenesis in prospective hemogenic endothelium and endocardium. Cell 150: 590-605. doi:10.1016/j.cell.2012.06.026

Verzi MP, McCulley DJ, De Val S, Dodou E, Black BL. 2005. The right ventricle, outflow tract, and ventricular septum comprise a restricted expression domain within the secondary/anterior heart field. Dev Biol 287: 134-145. doi:10 .1016/j.ydbio.2005.08.041

Vitelli F, Taddei I, Morishima M, Meyers EN, Lindsay EA, Baldini A. 2002. A genetic link between Tbx1 and fibroblast growth factor signaling. Development 129: 46054611.

Wamstad JA, Alexander JM, Truty RM, Shrikumar A, Li F, Eilertson KE, Ding H, Wylie JN, Pico AR, Capra JA, et al. 2012. Dynamic and coordinated epigenetic regulation of developmental transitions in the cardiac lineage. Cell 151: 206-220. doi:10.1016/j.cell.2012.07.035

Wang H, Yang H, Shivalila CS, Dawlaty MM, Cheng AW, Zhang F, Jaenisch R. 2013. One-step generation of mice carrying mutations in multiple genes by CRISPR/Cas- mediated genome engineering. Cell 153: 910-918. doi:10.1016/j.cell.2013.04.025

Wang W, Niu X, Stuart T, Jullian E, Mauck W, Kelly RG, Satija R, Christiaen L. 2019. A single cell transcriptional roadmap for cardiopharyngeal fate diversification. Nature Cell Biology 21: 674-686.

Watanabe Y, Miyagawa-Tomita S, Vincent SD, Kelly RG, Moon AM, Buckingham ME. 2010. Role of mesodermal FGF8 and FGF10 overlaps in the development of the arterial pole of the heart and pharyngeal arch arteries. Circ Res 106: 495-503. doi:10.1161/CIRCRESAHA.109 .201665

Watanabe Y, Zaffran S, Kuroiwa A, Higuchi H, Ogura T, Harvey RP, Kelly RG, Buckingham M. 2012. Fibroblast growth factor 10 gene regulation in the second heart field by Tbx1, Nkx2-5, and Islet1 reveals a genetic switch for down-regulation in the myocardium. Proc Natl Acad Sci 109: 18273-18280. doi:10.1073/pnas.1215360109

Wei Y, Mikawa T. 2000. Fate diversity of primitive streak cells during heart field formation in ovo. Dev Dyn 219: 505-513. doi:10.1002/1097-0177(2000)9999:9999<:: AID-DVDY1076>3.0.CO;2-6

Witzel HR, Jungblut B, Choe CP, Crump JG, Braun T, Dobreva G. 2012. The LIM protein Ajuba restricts the second heart field progenitor pool by regulating Isl1 activity. Dev Cell 23: 58-70. doi:10.1016/j.devcel.2012.06 .005

Wu SM, Fujiwara Y, Cibulsky SM, Clapham DE, Lien CL, Schultheiss TM, Orkin SH. 2006. Developmental origin of a bipotential myocardial and smooth muscle cell precursor in the mammalian heart. Cell 127: 1137-1150. doi:10.1016/j.cell.2006.10.028

Xavier-Neto J, Neville CM, Shapiro MD, Houghton L, Wang GF, Nikovits W Jr, Stockdale FE, Rosenthal N. 1999. A retinoic acid-inducible transgenic marker of sino-atrial development in the mouse heart. Development 126: 2677-2687.

Xu C, Liguori G, Persico MG, Adamson ED. 1999. Abrogation of the Cripto gene in mouse leads to failure of postgastrulation morphogenesis and lack of differentiation of cardiomyocytes. Development 126: 483-494.

Yang L, Soonpaa MH, Adler ED, Roepke TK, Kattman SJ, Kennedy M, Henckaerts E, Bonham K, Abbott GW, Linden RM, et al. 2008. Human cardiovascular progenitor cells develop from a $\mathrm{KDR}^{+}$embryonic-stem-cell-derived population. Nature 453: 524-528. doi:10.1038/na ture06894

Yoon C, Song H, Yin T, Bausch-Fluck D, Frei AP, Kattman S, Dubois N, Witty AD, Hewel JA, Guo H, et al. 2018. FZD4 marks lateral plate mesoderm and signals with NORRIN to increase cardiomyocyte induction from pluripotent stem cell-derived cardiac progenitors. Stem Cell Rep 10: 87-100. doi:10.1016/j.stemcr.2017.11.008

Yoshida T, Vivatbutsiri P, Morriss-Kay G, Saga Y, Iseki S. 2008. Cell lineage in mammalian craniofacial mesenchyme. Mech Dev 125: 797-808.

Yuan X, Song M, Devine P, Bruneau BG, Scott IC, Wilson MD. 2018. Heart enhancers with deeply conserved regulatory activity are established early in zebrafish development. Nat Commun 9: 4977. doi:10.1038/s41467-01807451-Z 
B. Swedlund and F. Lescroart

Zhang Q, Jiang J, Han P, Yuan Q, Zhang J, Zhang X, Xu Y, Cao H, Meng Q, Chen L, et al. 2011. Direct differentiation of atrial and ventricular myocytes from human embryonic stem cells by alternating retinoid signals. Cell Res 21: 579-587. doi:10.1038/cr.2010.163

Zhang J, Tao R, Campbell KF, Carvalho JL, Ruiz EC, Kim GC, Schmuck EG, Raval AN, da Rocha AM, Herron TJ, et al. 2019. Functional cardiac fibroblasts derived from human pluripotent stem cells via second heart field progenitors. Nat Commun 10: 2238. doi:10.1038/s41467019-09831-5

Zhou Z, Wang J, Guo C, Chang W, Zhuang J, Zhu P, Li X. 2017. Temporally distinct Six2-positive second heart field progenitors regulate mammalian heart development and disease. Cell Rep 18: 1019-1032. doi:10.1016/j.celrep.2017 .01 .002 


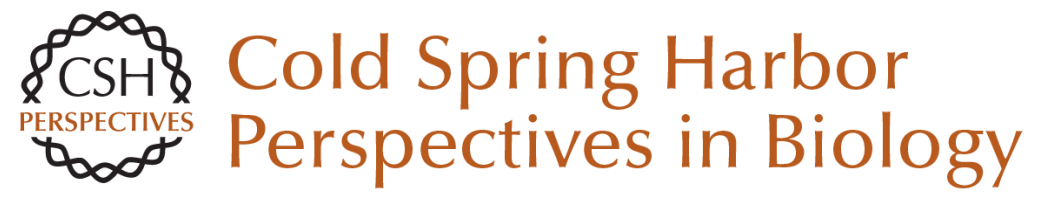

\title{
Cardiopharyngeal Progenitor Specification: Multiple Roads to the Heart and Head Muscles
}

\author{
Benjamin Swedlund and Fabienne Lescroart
}

Cold Spring Harb Perspect Biol 2020; doi: 10.1101/cshperspect.a036731 originally published online December 9, 2019

\section{Subject Collection Heart Development and Disease}

Epicardium in Heart Development

Yingxi Cao, Sierra Duca and Jingli Cao

Cardiac Neural Crest

Hiroyuki Yamagishi

The Endocardium and Heart Valves Bailey Dye and Joy Lincoln

Long Noncoding RNAs in Cardiac Development Michael Alexanian and Samir Ounzain

Genetic Basis of Human Congenital Heart Disease Shannon N. Nees and Wendy K. Chung

Cardiopharyngeal Progenitor Specification: Multiple Roads to the Heart and Head Muscles Benjamin Swedlund and Fabienne Lescroart

Genetic and Epigenetic Control of Heart Development Brynn N. Akerberg and William T. Pu

Formation and Growth of Cardiac Lymphatics during Embryonic Development, Heart Regeneration, and Disease

Dana Gancz, Gal Perlmoter and Karina Yaniv
In Vivo and In Vitro Genetic Models of Congenital

Heart Disease Uddalak Majumdar, Jun Yasuhara and Vidu Garg

Development of the Cardiac Conduction System

Samadrita Bhattacharyya and Nikhil V. Munshi

3D Anatomy of the Developing Heart:

Understanding Ventricular Septation

Timothy J. Mohun and Robert H. Anderson

Cardiac Morphogenesis: Specification of the

Four-Chambered Heart

Vincent Christoffels and Bjarke Jensen

The Chicken as a Model Organism to Study Heart

Development

Johannes G. Wittig and Andrea Münsterberg

The First Heartbeat--Origin of Cardiac Contractile

Activity

Richard C.V. Tyser and Shankar Srinivas

Xenopus: Experimental Access to Cardiovascular

Development, Regeneration Discovery, and

Cardiovascular Heart-Defect Modeling

Stefan Hoppler and Frank L. Conlon

Reptiles as a Model System to Study Heart

Development

Bjarke Jensen and Vincent M. Christoffels

For additional articles in this collection, see http://cshperspectives.cshlp.org/cgi/collection/

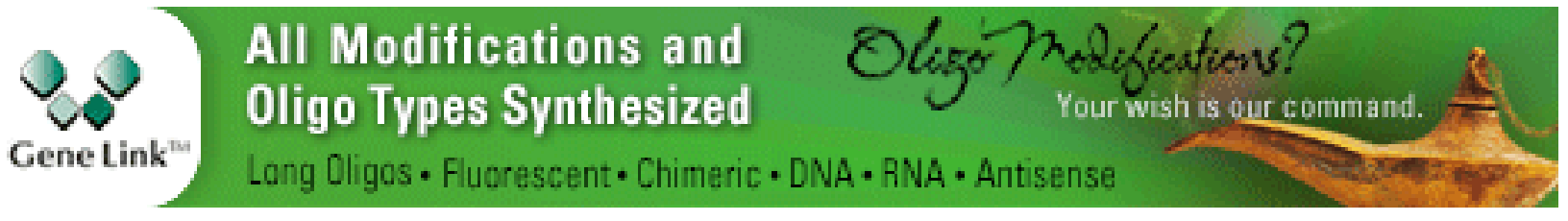

Copyright @ 2020 Cold Spring Harbor Laboratory Press; all rights reserved 